Amasya Ilahiyat Dergisi - Amasya Theology Journal

ISSN 2667-7326 | e-ISSN 2667-6710

Haziran / June 2020, 14: 327-351

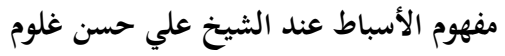

\title{
Şeyh Ali Hasan Galum'a Göre Esbât Kavramı
}

\section{al-Asbât According to Sheikh Ali Hasan Galum}

\author{
Zehra Betül GÜNEY \\ Dr., Sakarya Üniversitesi, İlahiyat Fakültesi, \\ Arap Dili ve Belâgatı Ana Bilim Dalı \\ Phd., Sakarya University, Faculty of Theology, \\ Department of Arabic Language and Literature \\ Sakarya, Turkey \\ zbguney@sakarya.edu.tr \\ orcid.org/0000-0002-9203-8406
}

\section{Makale Bilgisi / Article Information}

Makale Türü / Article Types: Araştırma Makalesi / Research Article

Geliş Tarihi / Received: 30 Mart / March 2020

Kabul Tarihi / Accepted: 5 Mayıs / May 2020

Yayın Tarihi / Published: 30 Haziran / June 2020

Yayın Sezonu / Pub. Date Season: Haziran / June

Sayı / Issue: 14 Sayfa / Pages: 327-351

Atıf / Cite as: Güney, Zehra Betül. "مفهوم الأسباط عند الشيخ علي حسن [al-Asbât According To Sheikh Ali Hasan Galum]". Amasya Ilahiyat Dergisi-Amasya Theology Journal 14 (June 2020): 327-351.

https://doi.org/10.18498/amailad.711714.

İntihal / Plagiarism: Bu makale, en az iki hakem tarafından incelendi ve intihal içermediği teyit edildi. / This article has been reviewed by at least two referees and scanned via a plagiarism software.

Copyright @ $\odot$ Published by Amasya Üniversitesi, İlahiyat Fakültesi / Amasya University, Faculty of Theology, Amasya, 05100 Turkey. All rights reserved. https://dergipark.org.tr/amailad. 


\section{al-Asbât According to Sheikh Ali Hasan Galum}

\section{Abstract}

al-Asbât in Islamic thought is a controversial concept among Shia and Sunni schools. Sunni school believes that they all were the brothers of Prophet Joseph and were Prophets. Yet, Shia school rejects the idea that al-Asbât were Prophets, due to the big sins they committed. Some of Shia sholars think that al-Asbât were Wasiyy (Legatee) of Prophets. Sheikh Ali Hasan Galum adds a new idea to al-Asbât by arguing the similarity between the concept of al-Asbât in Quran with those Judges in Torah. He gives the concept of Judges and al-Asbât as a reference to Twelve Imams. This article, after explaining the concept of Judges in Judaism, will deal with the concept of al-Asbât in Sunni sources. After that it will explain the meaning of al-Asbât generally in Shia thought. Then it will touch upon the similarity of the Judges with the concept of Twelve Imams which has handled for the first time by Sheikh Galum in Shia thought.

\section{Summary}

al-Asbât, whose number is twelve and mentioned as the descendant of the Prophet Jacob in Islamic thought, is a controversial concept among Shia and Sunni schools. Both schools agree on the meaning of al-Asbât, which means the son of the son, grandson, the son of the daughter or the notable sons. But they differ in content and details of al-Asbât. Eventhough, the thought that al-Asbât are the eleven brothers of Prophet Joseph and all of them were Prophets is prevailing idea in Sunni literature, they differed on the identity of al-Asbât. Some of them claimed that they were Prophet Joseph's brothers and they became Prophets after repentance and seeking forgiveness and asking Allah for His mercy for the sins and crimes they had committed. Besides, Sunni scholars do not refer to the Hadiths in which Hasan and Hussein were mentioned as alAsbât while they interpreting the verse in which al-Asbât is mentioned there too. Contrary to Shia school that rejects the idea of al-Asbât were the brothers of Prophet Joseph and the idea that all of them were Prophets, due to the big sins they committed to their brothers Prophet Joseph. Shiites believe that Allah when mentioned to the brothers of Prophet Joseph in verses and when He told their attitude towards their fathers, Prophet Jacob, He did not use glowing and bright words about them. Far from it, He used a very humiliating and accusatory language about them in verses. Therefore, unlike other Prophets' biographies, which have lived a commendable life since their childhood, a devout and purist profile was not drawn about them in Quran. Some contemporary Shia scholars link the hadiths reported in Hasan and Hussein as 
al-Asbât with the verses in which the word al-Asbât are mentioned. They point to the similarity between Prophet Moses and Prophet Mohammad, and Haroun and Ali ibn Ebi Talib, and between the nation (ummah) of Prophet Moses and the nation of Mohammad in terms of differentiation. They defend that the surviving groups in Prophet Mohammad's ummah are Ahlu'l-bayt (family of Prophet Mohammad) and those who followed them, as well as who acknowledged that Ali ibn Ebi Talib and his twelve sons are sinless Imams (leaders) which should be emulated. There are contemporary Shiite scholars who go on to say that when the Prophet Mohammad mentioned Hussein as alAsbât, he did not mean that he was his grandson. Rather, He wanted to reveal the similarity between His grandson and al-Asbât which mentioned in Quran. So, they think that those al-Asbât were Wasiyy (Legatee) of Prophets. They argue that, when Allah mentioned al-Asbât in verses with those Prophets, He meant that $\mathrm{He}$ is in connection with them as well as in connection with Prophets, but by inspiration and another kind of revelation that differed from his revelation to the Prophets. There are some of other Shia sholars added another meaning to the word al-Asbât. They argue that the Judges in Torah are the Wasiyy of Prophets who lived in inter-Prophethood era. They point out that al-Asbât were like Judges in their statue, they not only ruled over the community with justice, but also were the successors and the guardians of Prophets' secret knowledge, as well as divine models for human being to follow. As Allah sent Judges to the Jews to save them from perdition, the Prophet Mohammad appointed Ali ibn Ebi Talib and his sons as Judges of his ummah. Kwaiti Shiite scholar Sheikh Ali Hasan Galum adds more new idea to al-Asbât by arguing the similarity between Twelve Imams with those Judges in Torah. He gives the concept of Judges and alAsbât as a reference to Twelve Imams by addressing the similarity and common denominator between them. He combined the concept of Judges with the concept of al-Asbât in Wasayah (guardianship) and Imamamate (legitimate successor). He went on to say that the counterpart of Prophet Moses in Islam is Prophet Mohammad, and the counterpart of Jashua is Ali ibn Ebi Talib, and the counterpart of Deborah, the only woman in the Judges, is Fatima bint Mohammad (daughter of Prophet). And the rest of the Judges are counterparts of the sons of Ali ibn Ebi Talib, whose numbers are eleven. This article, after explaining the concept of al-Asbât and Judges in Judaism, will deal with the concept of al-Asbât in Sunni sources. After that, it will explain the meaning of alAsbât generally in Shia thought. Then it will touch upon the similarity of the Judges in Judaism with the concept of Twelve Imams which has handled for the first time by Sheikh Galum in Shia thought. 
330 | Z. B. GÜNEY / مفهوم الأسباط عند الشيخ علي حسن غلوم

Keywords: Islamic Sects, Shia, Twelve Imams, al-Asbât, Torah.

\section{Öz}

\section{Şeyh Ali Hasan Galum'a Göre Esbât Kavramı}

Hz. Yakup'un soyundan gelen ve sayıları on iki olan Esbât, İslam duşuncesinde tartışmalı olan bir husustur. Sunni literaturde istisnalar olsa da, genel olarak Esbât'ın Hz. Yusuf'un kardeşleri olduğu ve bunların hepsinin Peygamberler olduğu duşuncesi hâkimken, Şii duşunce Hz. Yusuf'un kardeşlerinin Peygamber olduğu fikrini işledikleri buyuk gunahlar yuzunden reddetmektedir. Sunni ekol, on bir kardeşin tövbe ettiği için Peygamber olmalarına mumkun gözuyle bakarken, Şii ekol Peygamberlerin buyuk gunahlardan munezzeh olduklarının altını çizerek Kur'an'da zikri geçen Esbât'in Hz. Yakup'un soyundan gelen başka Peygamberler olduğuna dikkatleri çekmiştir. Bazı modern dönem Şii alimleri Esbât'ın Peygamberler olmadığını, Peygamberler arası dönemde yaşamış Vasîler olduklarını savunmuştur. Kuveytli bir Şii alim olan Şeyh Ali Hasan Galum ise bu kavrama yeni bir bakış açısı getirerek, Kur'an'da geçen Esbât'ın Tevrat'ta geçen Hâkimler olduklarına, bunların On İki Imam gibi Peygamberler arası dönemde Peygamberlerin Vasîleri ve Velileri olarak yaşamış ve toplumda adaleti sağlamakla mukellef liderler olduklarına dikkatleri çekmiştir. Bununla, Tevrat'taki Hakimler olgusunu On İki İmam inancına referans olarak göstermeye çalışmıştır. Bu makalede, öncelikle Tevrat'ta geçen Esbât ve Hakimler kavramını ele aldıktan sonra Esbât kavramını önce Sünni kaynaklarda daha sonra da genel olarak Şii kaynaklarda nasıl ele alındığını kaleme alacağız. Daha sonra Şeyh Galum tarafından ilk defa Şii ekolde ele alınan Hakimler hususunu On İki İmam inancına referans olarak göstermesine ve bu kavramla ilişkilendirmesine değineceğiz.

Anahtar Kelimeler: Mezhepler Tarihi, Şiilik, On İki İmam, Esbât, Tevrat.

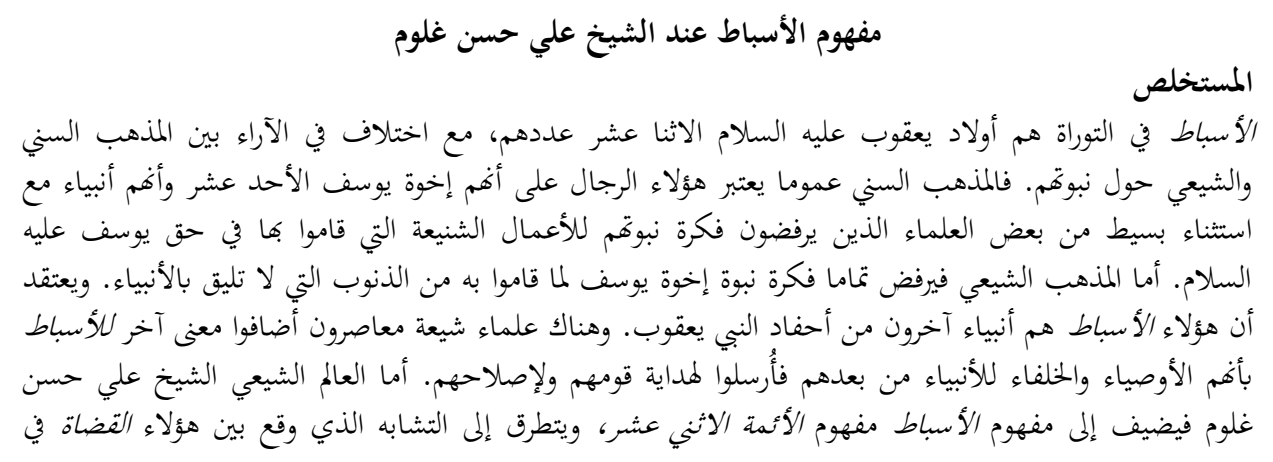


Z. B. GÜNEY / al-Asbât According to Sheikh Ali Hasan Galum | 331

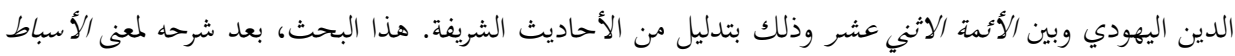

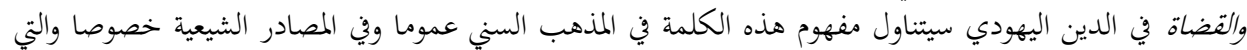

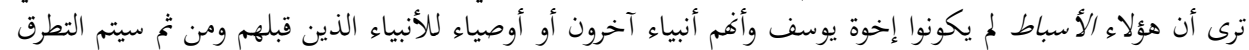

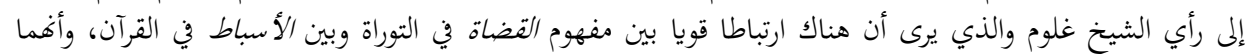

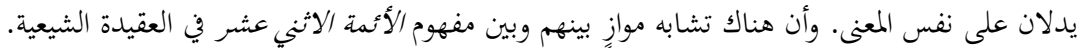
الأسباط هم جماعة من الناس تناولت التوراة والقرآن ذكرهم. وقد تناولتهم التوراة والمصادر الإسلامية عموما على أغمم

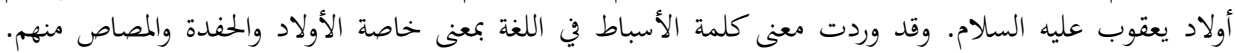

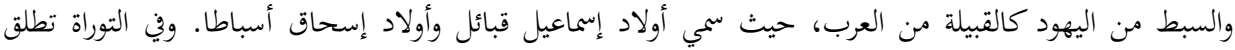

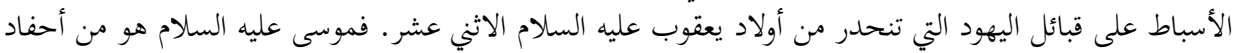

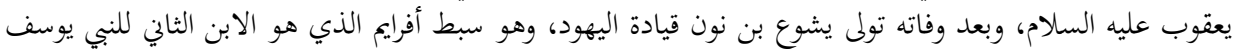

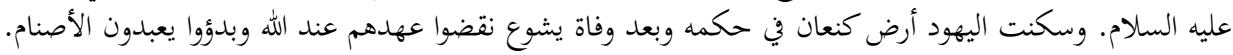

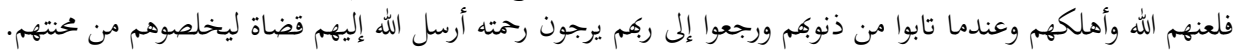

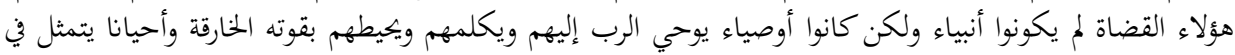

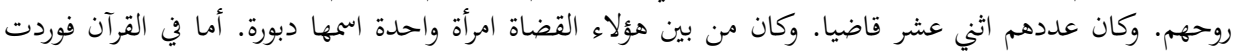

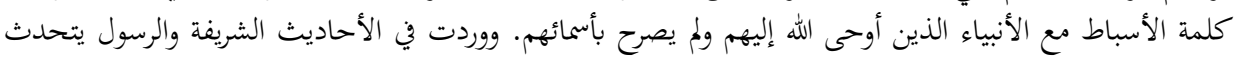

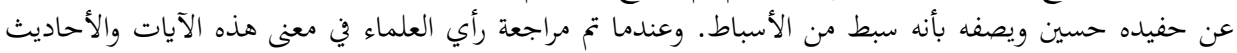

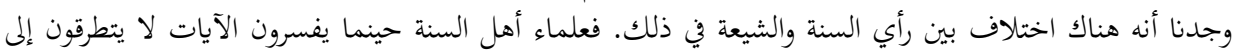

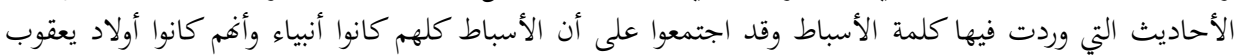

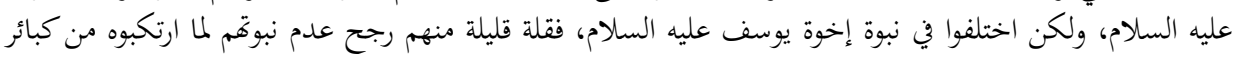

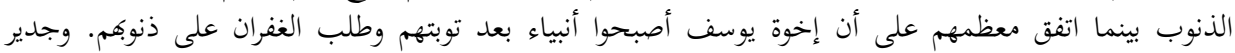

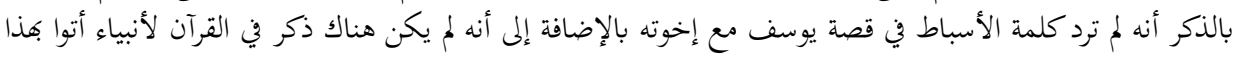

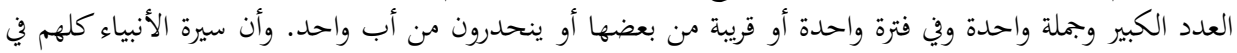

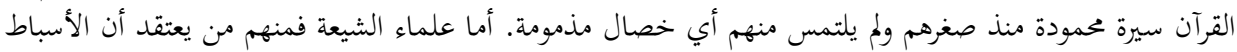

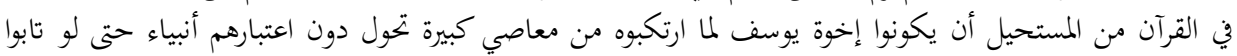

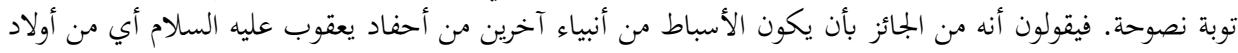

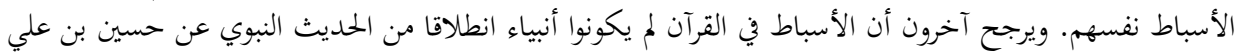

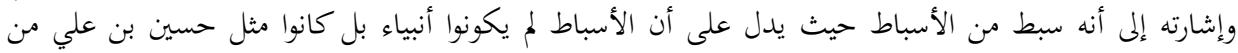

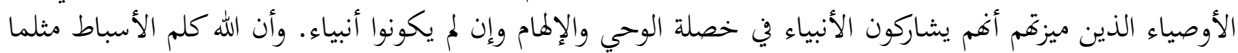

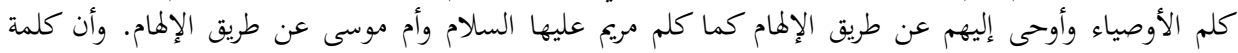

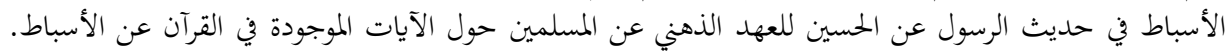

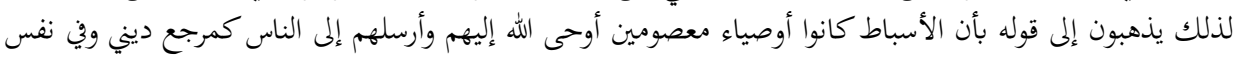

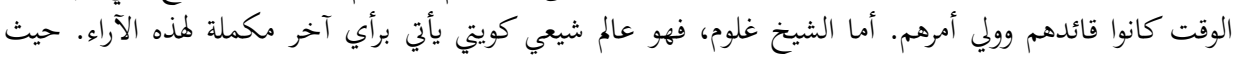

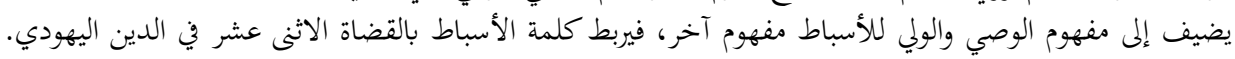

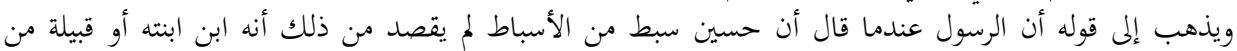

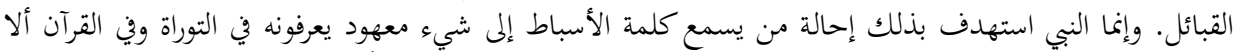

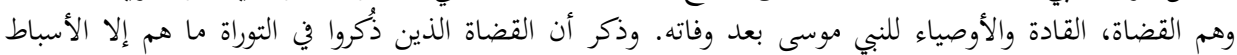

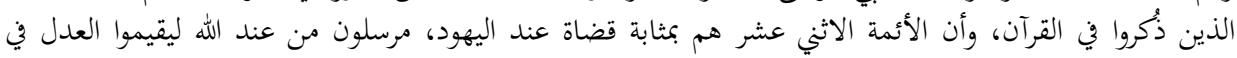




\section{2 | Z. B. GÜNEY / مفهوم الأسباط عند الشيخ علي حسن غلوم}

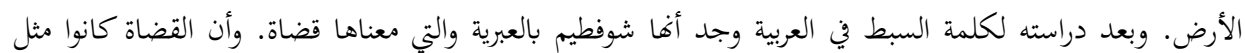

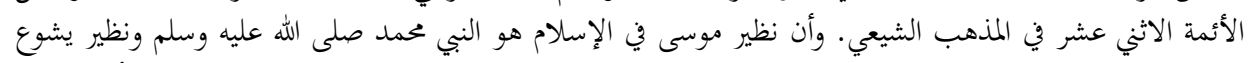

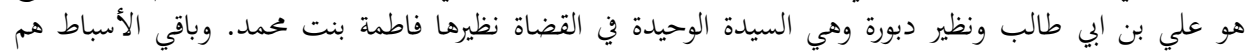

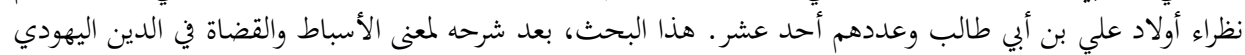

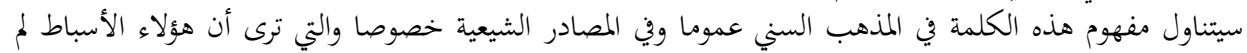

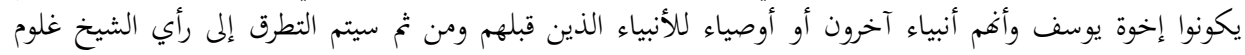

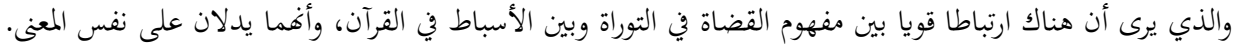

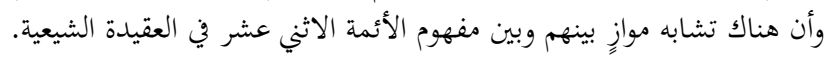

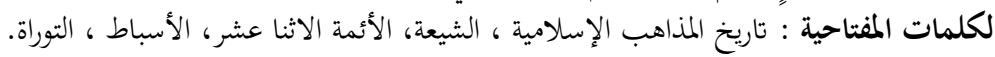

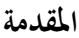

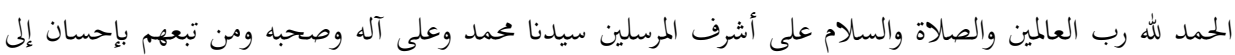

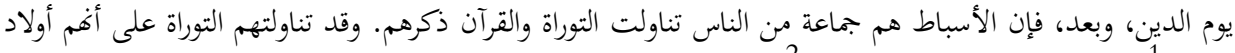

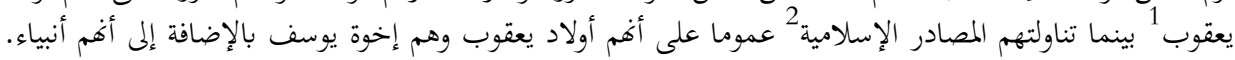

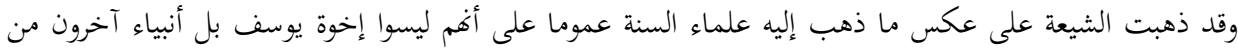

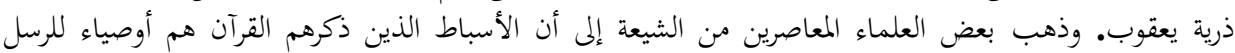

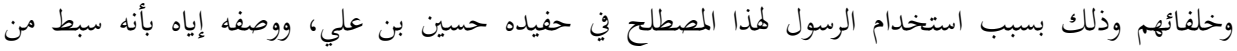

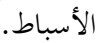

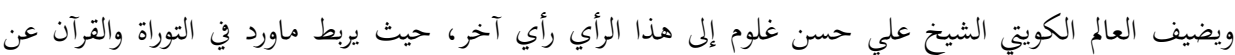

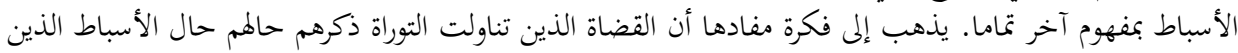

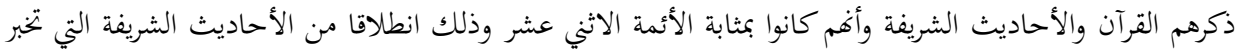

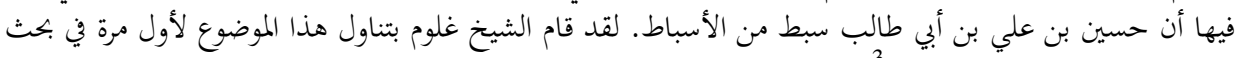

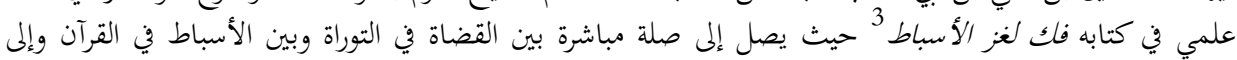

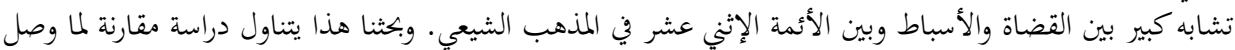

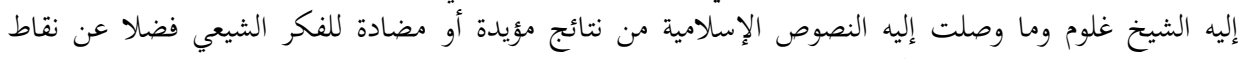

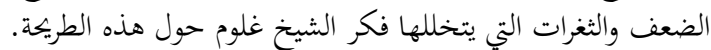

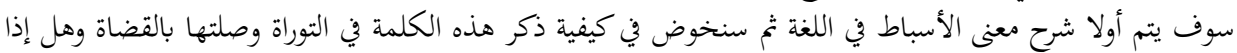

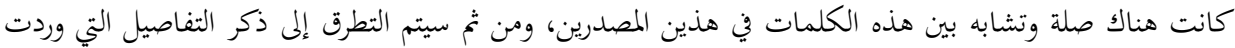

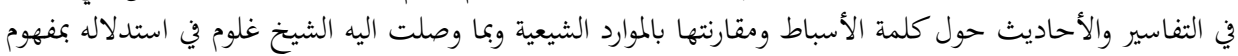

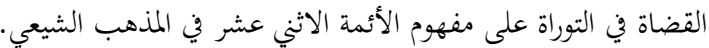

1 1. معنى كلمة الأسباط عند اللغويين

$$
\begin{aligned}
& 1 \text { سفر الخروج 28/49. } \\
& \text { 22 سوف يتم التطرق الى هذه المصادر كلها في الصفحات القادمة. }
\end{aligned}
$$

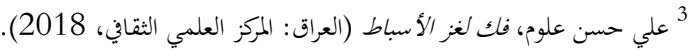


Z. B. GÜNEY / al-Asbât According to Sheikh Ali Hasan Galum | 333

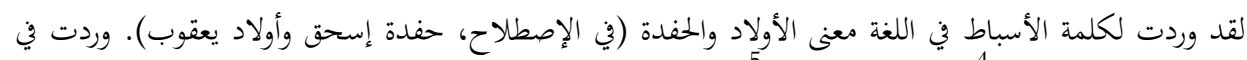

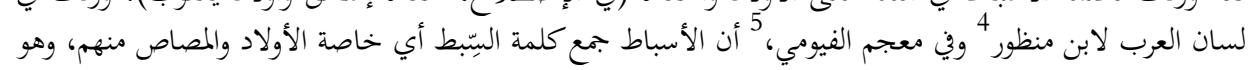

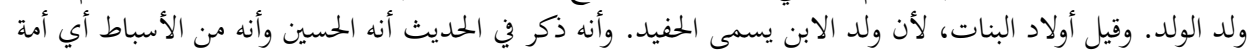

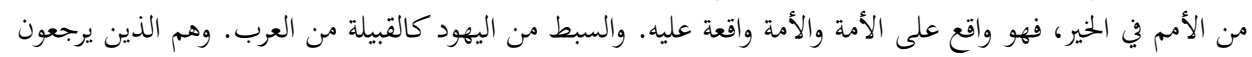

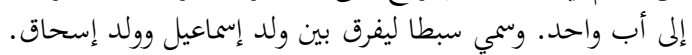

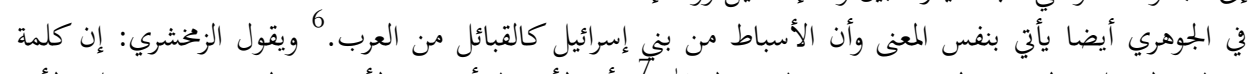

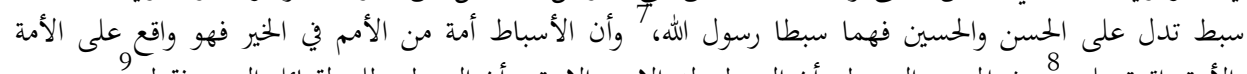

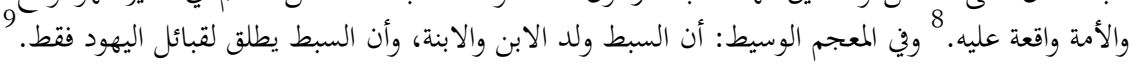

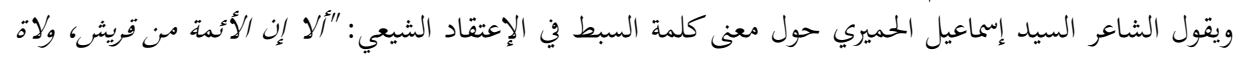

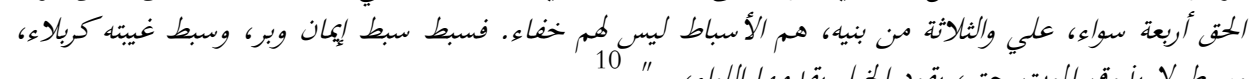

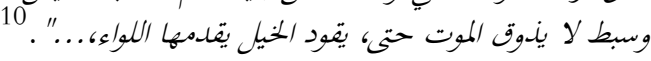

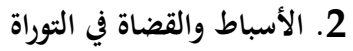

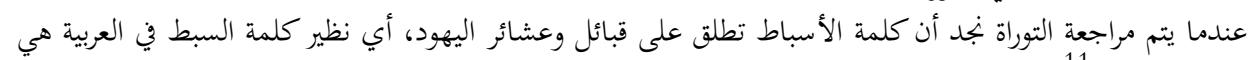

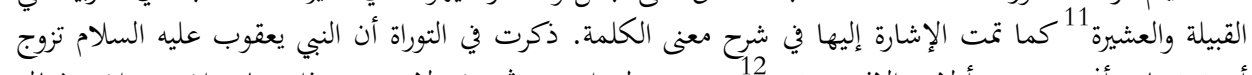

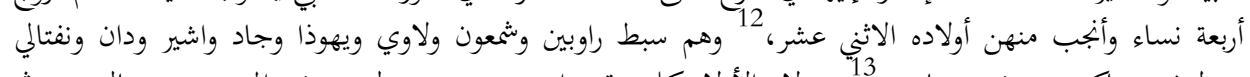

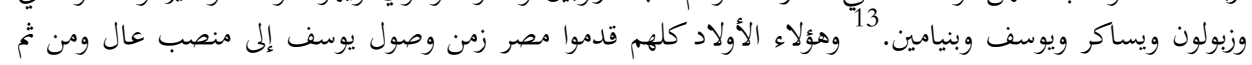

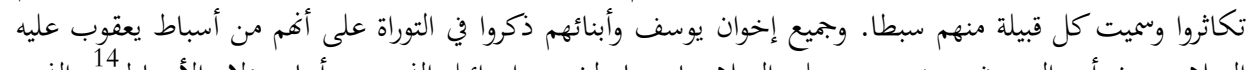

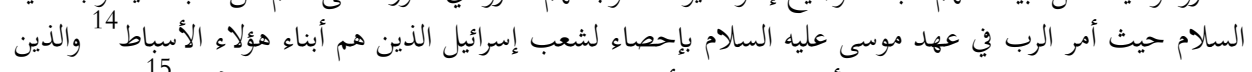

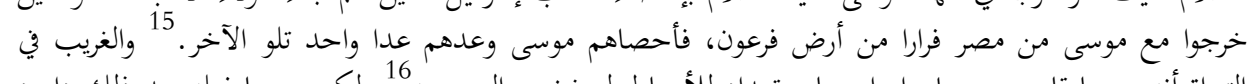

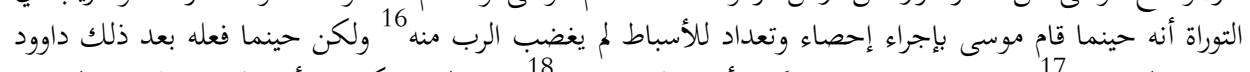

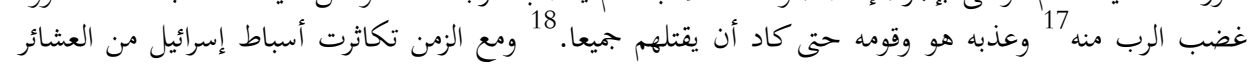

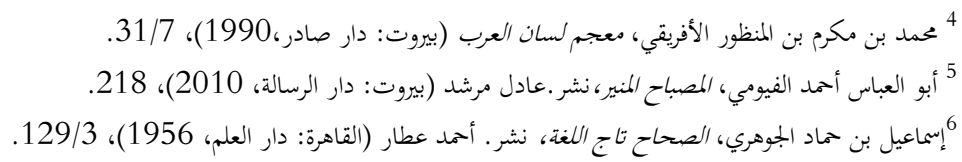

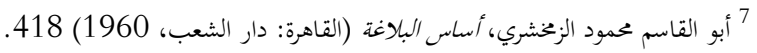

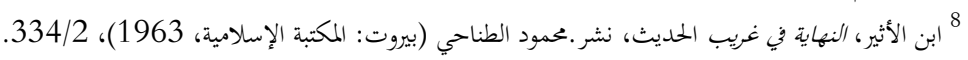

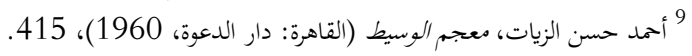

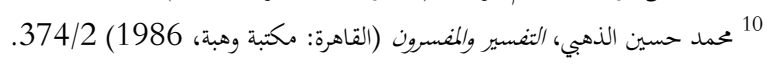

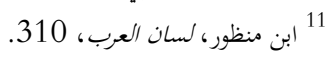

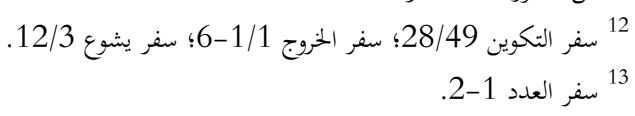

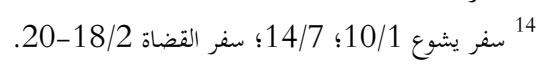

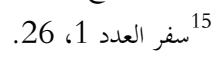

16 سفر العدد 1/1-17

18 فهذا التناقض في الأفعال وتصرفات مضطربة والإنفصام العقلي سمة تتسم به رب اليهود في التوراة (حاشا لله من ذلك).

18

Amasya Theology Journal, 14 (June 2020): 327-351 
334 | Z. B. GÜNEY / مفهوم الأسباط عند الشيخ علي حسن غلوم

والقبائل ووصل عددهم الى ستمائة ألف. 19 وذكرت في التوراة أن الأسباط مهما تكاثروا فأصلهم يعود إلى هؤلاء

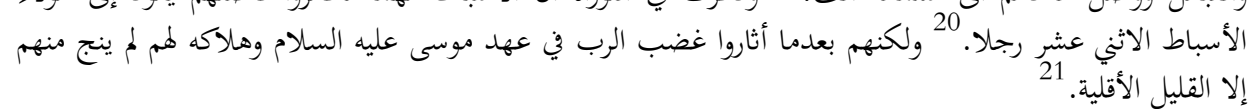

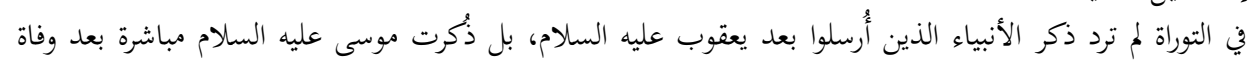

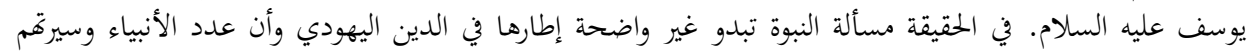

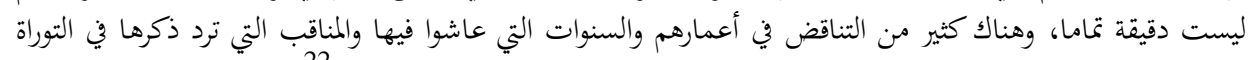

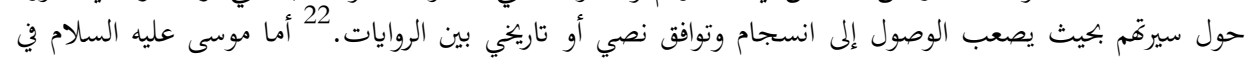

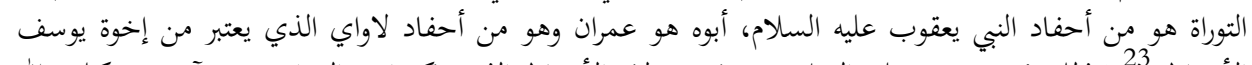

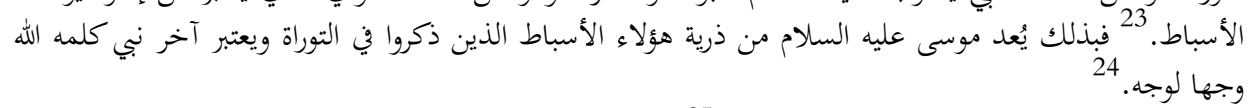

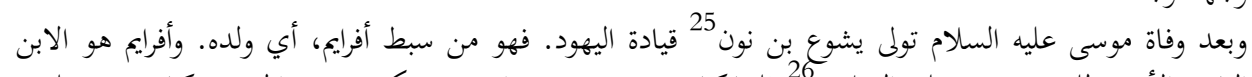

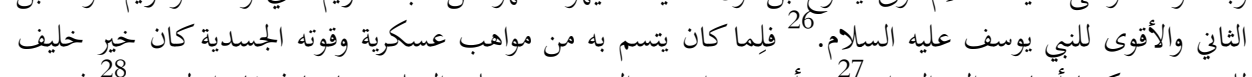

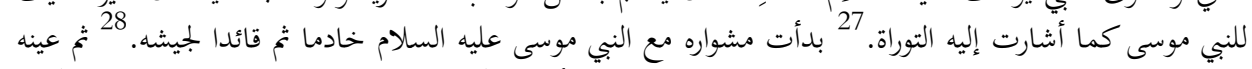

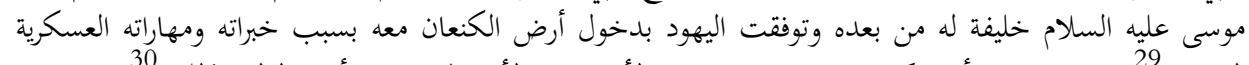

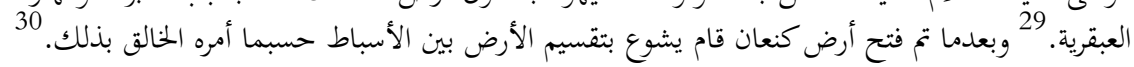

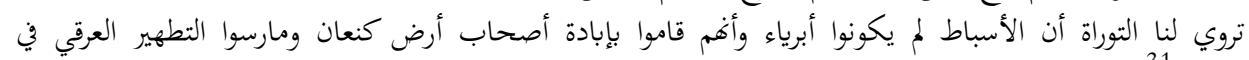

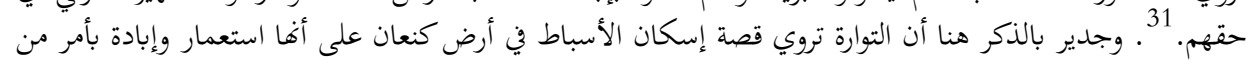

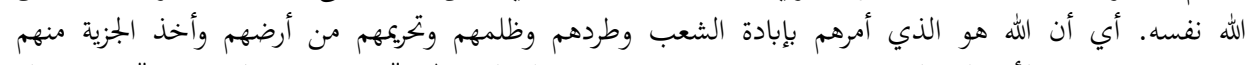

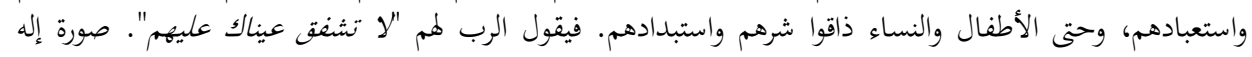

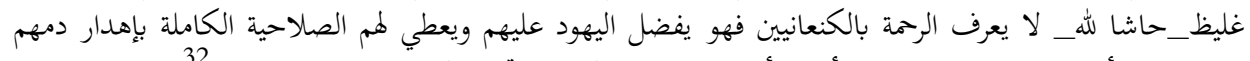

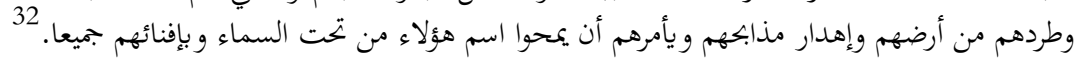

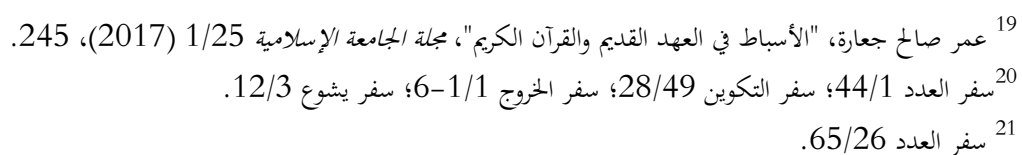

Walther Zimmerli, The law and the prophets (USA: Wipf \& Stock Publishers, 2010), 60-63. ${ }^{22}$

$$
\begin{aligned}
& 23 \\
& \text { 24 سفر التثنية 10/34. } \\
& \text { 25 وردت في التفاسير الإسلامية أن يشوع هو الفتى الذي كان يرافق موسى عليه السلام (الكهف 62/18). } \\
& 26 \text { سفر التكوين 6/48. }
\end{aligned}
$$

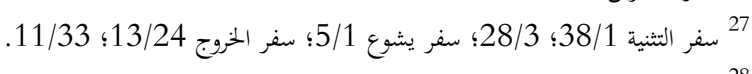

$$
\begin{aligned}
& 28 \text { سفر الخروج 24/13؛ 19/17 سفر الثين }
\end{aligned}
$$

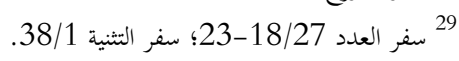

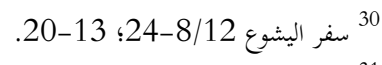

$$
\begin{aligned}
& 31 \text { سفر الخروج 29/23-32؛ سفر التنية 12/2-13/24، 23-25؛ 25/11؛ سفر اليشوع 10/16، 13/17. } \\
& 32 \text { سفر التنينية } 7 .
\end{aligned}
$$


Z. B. GÜNEY / al-Asbât According to Sheikh Ali Hasan Galum | 335

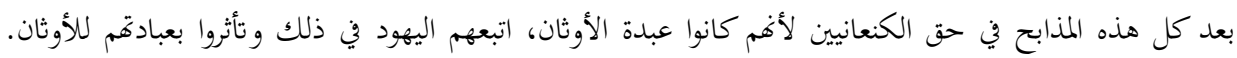

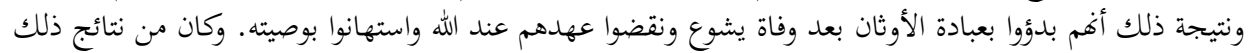

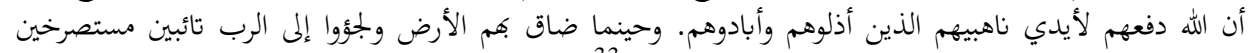

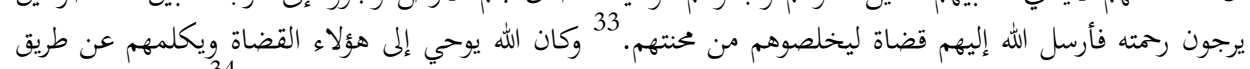

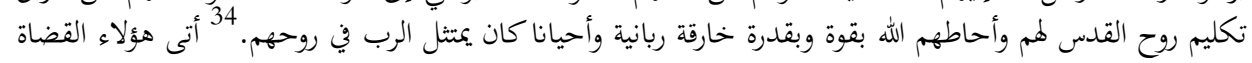

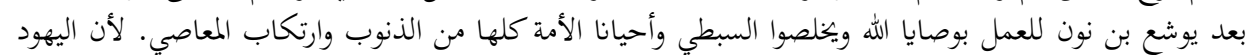

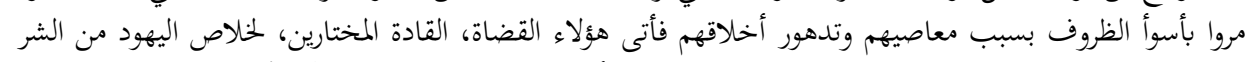

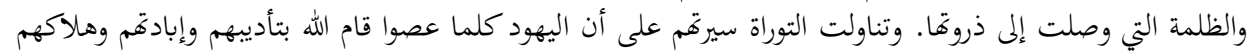

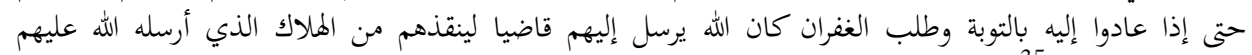

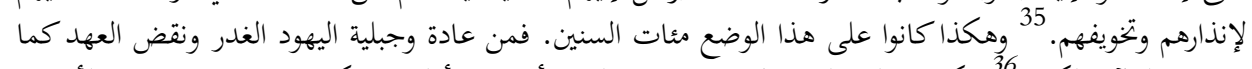

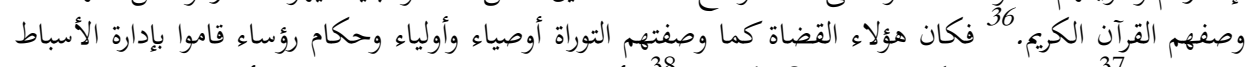

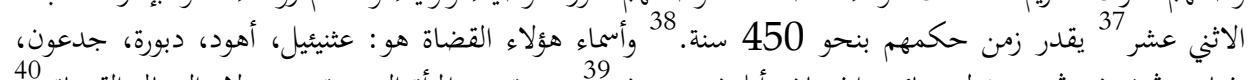
يفتاح، شمشون، شمجر، تولع، يائير، ايفسان، أيلون، عبدون.

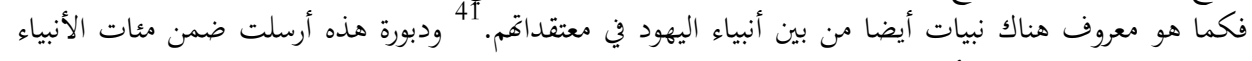

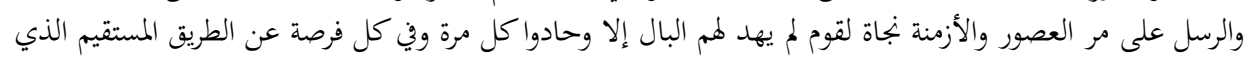
ربمه لفم ربهم.

\section{3. الأسباط في القرآن وفي الأحاديث النبوية}

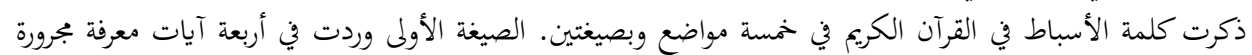

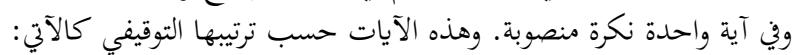

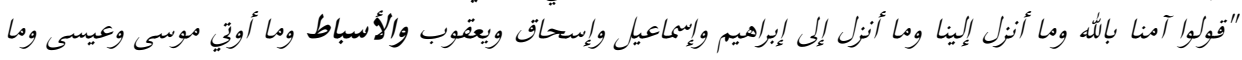

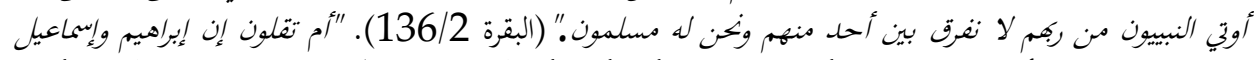

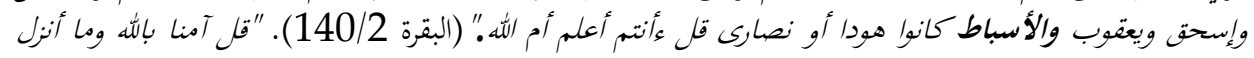

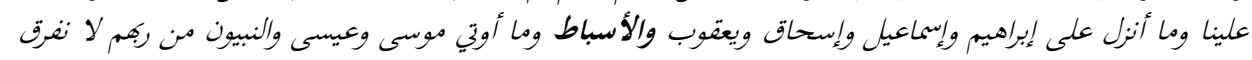

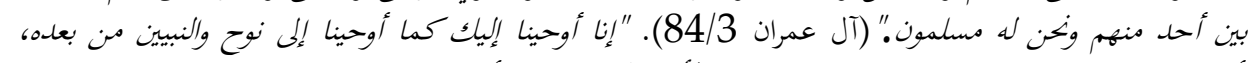

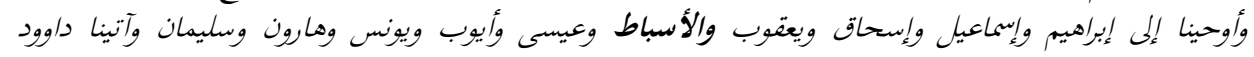

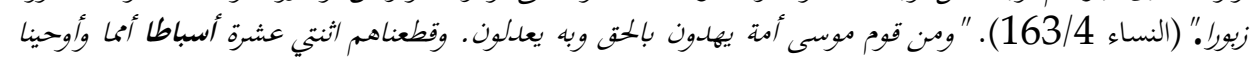

$$
\begin{aligned}
& 33 \\
& \text { 34 سفر القضاة 10/3؛ 34/6؛ 6/14 القضاة }
\end{aligned}
$$

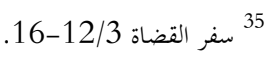

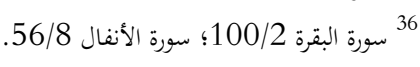

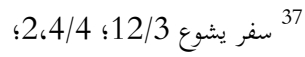

$$
\begin{aligned}
& \text { 38 ماكسيموس صموئيل، دراسة في سفر القضاة، 5؛ سفر القضاة 16/2، } \\
& 39 \text { سفر القضاة 3-12. } \\
& 40 \\
& \text { 41 سفر الخروج 20/15؛ سفر الملوك الثاني 14/22؛ سفر إرميا 14/6. }
\end{aligned}
$$


336 | Z. B. GÜNEY / مفهوم الأسباط عند الشيخ علي حسن غلوم

إلى موسى إذ استسقاه قومه أن اضرب بعصاك الحجر فانبجست منه اثنتا عشرة عينا قد علم كل أناس مشركمب...

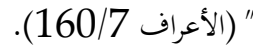

لقد وردت كلمة الأسباط في حديث والحد وافد وذكر في هذا الحديث حسين بن علي بأنه سبط من الأسباط. هذا

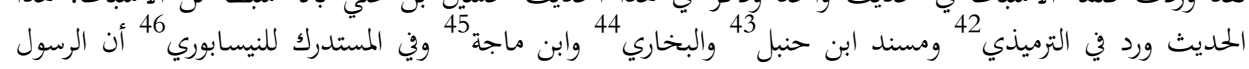

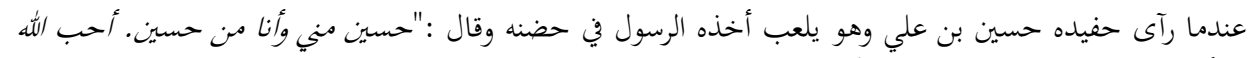

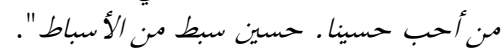
وبعد طرح جميع النصوص حول كلمة الأسباط في القرآن والحديث الحسيث النبوي سنستدرج فيما يلي أجوبة على أسئلة

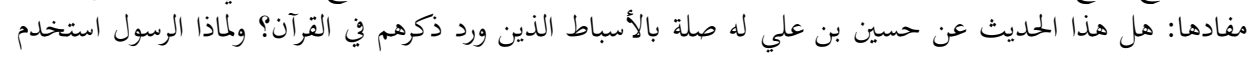

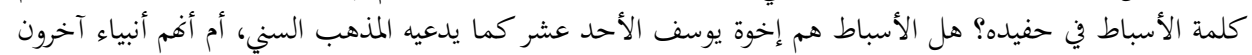

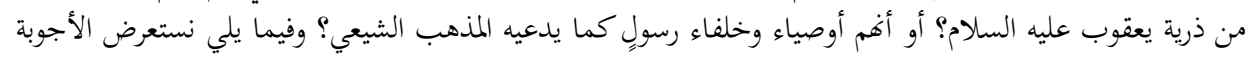

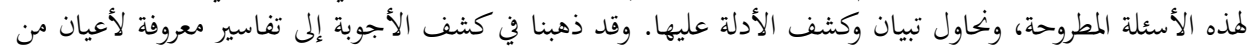

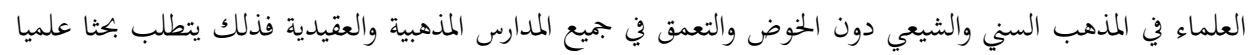

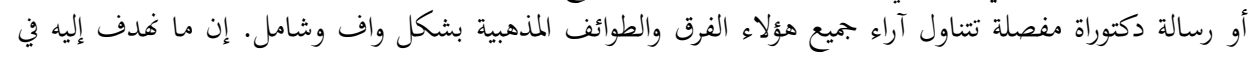

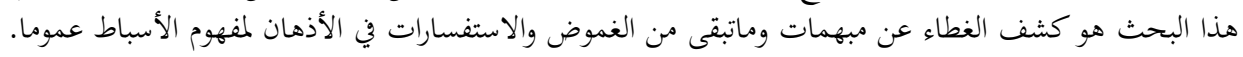

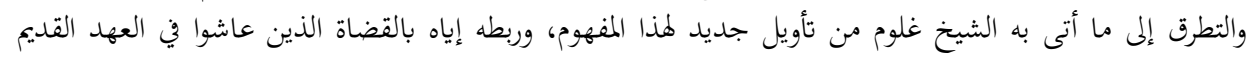

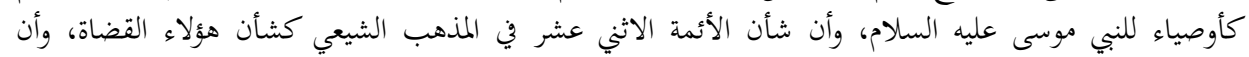

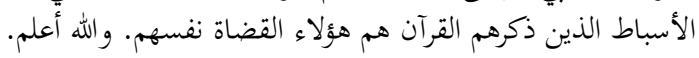

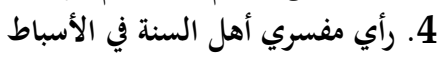

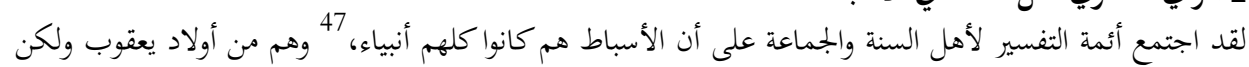

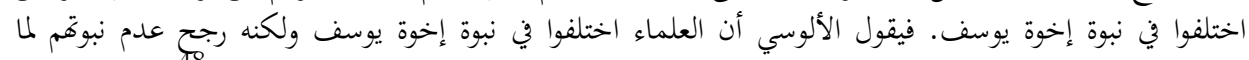

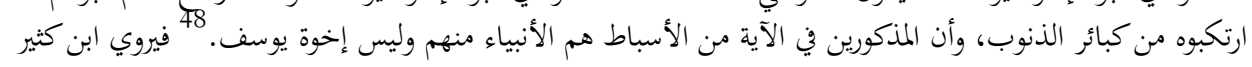

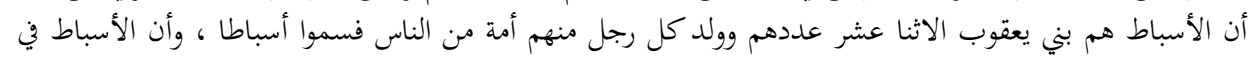

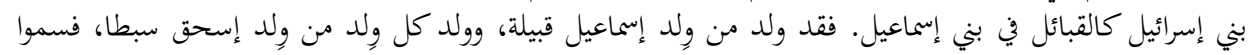

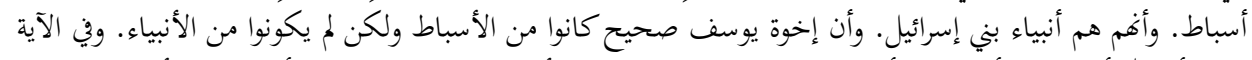

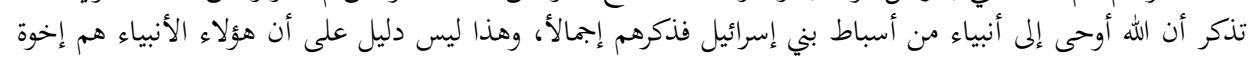

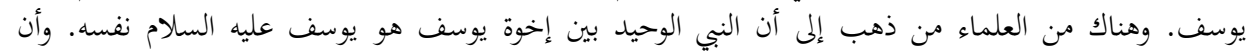

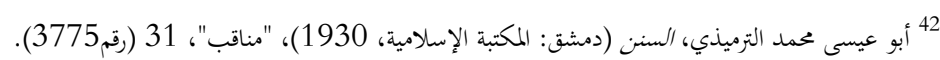

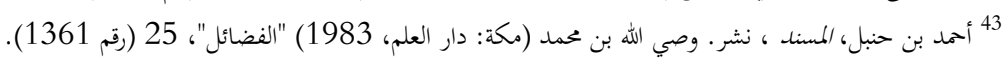

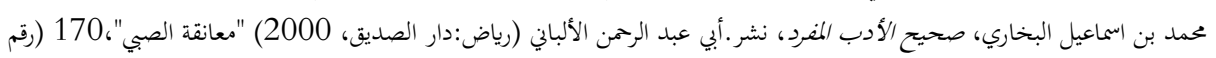

أبو عبد الله محمد بن ماجة، سنن ابن ماجة، نشر . محمد عبد الباقي (القاهرة: دار الكتب العربية، 1930) "فضائل الصحابة"، 11 (رقم

محمد بن الحاكم النيسابوري، المستدرك، نشر . مصطفى عبد القادر العطا (بيروت: دار الكتب، 1990) "معرفة الصحابة"، 418 (رقم . $\left(4820^{46}\right.$

47 عمر عبد الوهاب محمود،"الأسباط في القرآن الكريع"، مجلة آداب الرافدين 55/9 (1508)، (2008)، 18.

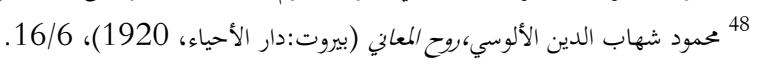


Z. B. GÜNEY / al-Asbât According to Sheikh Ali Hasan Galum I 337 البخاري روى أن النبي يعقوب حذر يوسف من أن يقص رؤيته إلى إخوته فيكيدوا له، وهذا مخالف على عصمة الأنبياء من كبائر الذنوب روى أنبي يعنوب

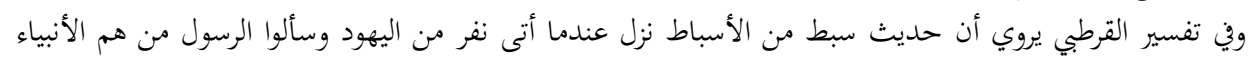

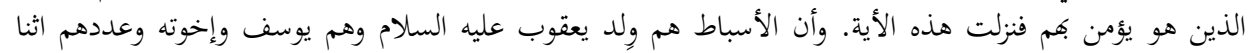

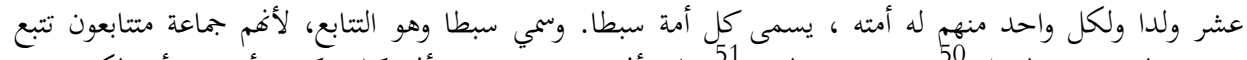

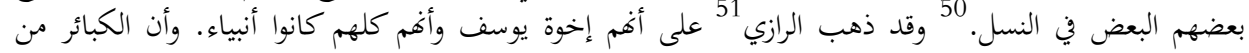

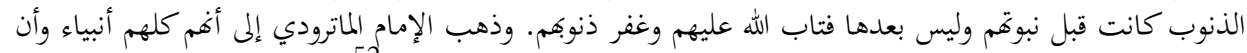

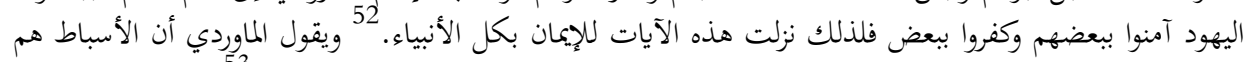

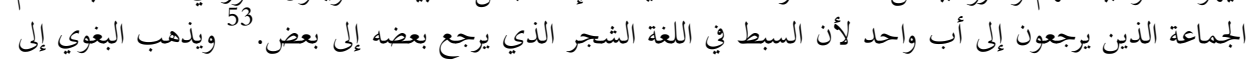

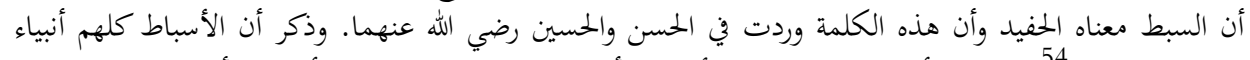

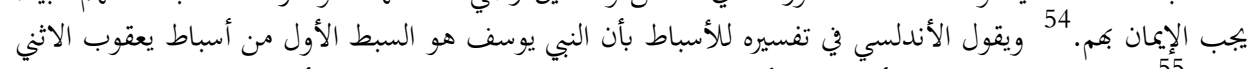

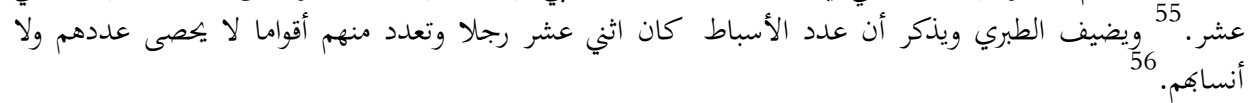
وأتت كلمة أسباط معرفة في كل الآيات إلا في سورة الأعراف أتت نكرة وأتت مؤنثة وفي نفس الوقت على الته صيغة جمع.

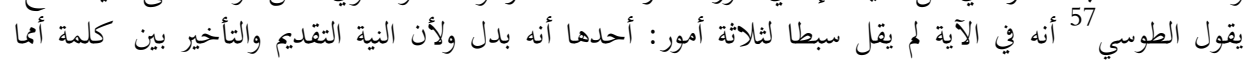

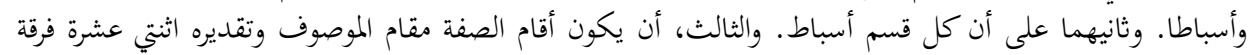

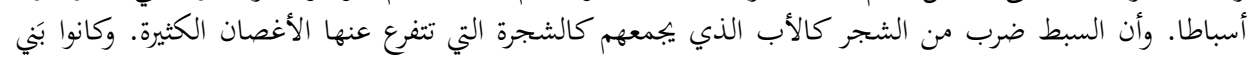

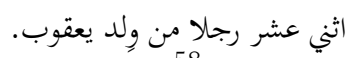

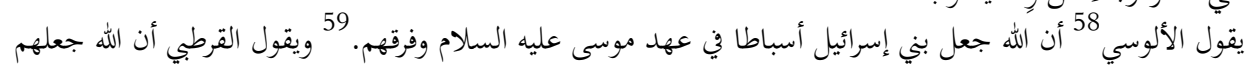

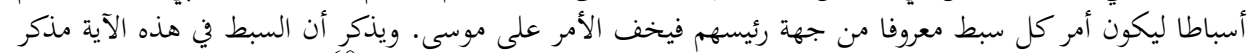

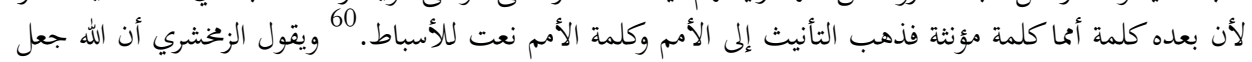

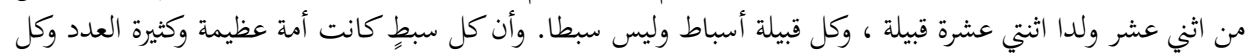

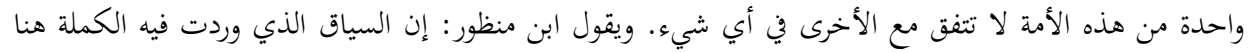

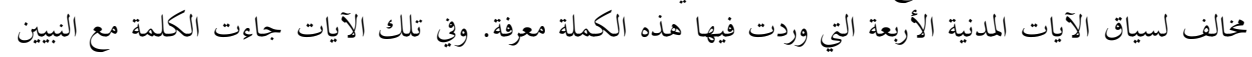

$$
\begin{aligned}
& 49 \text { عماد الدين أبى الفداء إسماعيل بن كثير، تفسير ابن كثير (حلب: دار الأحياء، 1987)، 1957)، 208/4. }
\end{aligned}
$$

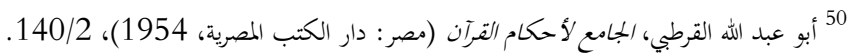

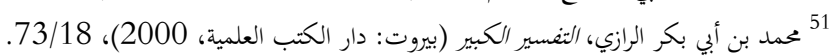

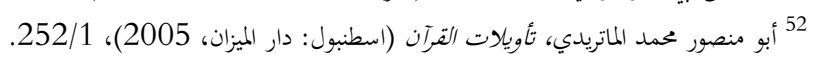

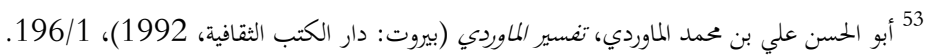

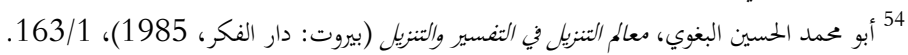

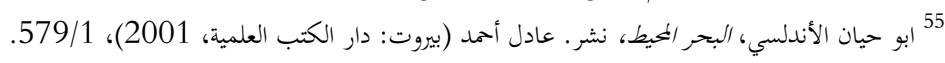

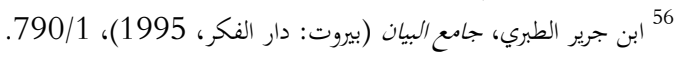

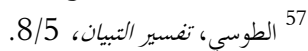

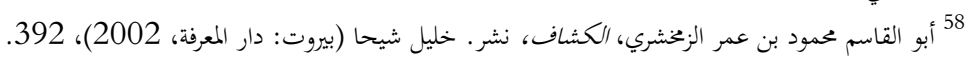

$$
\begin{aligned}
& \text { } 59 \text { 5الألوسي، روح المعاني، 185/12. }
\end{aligned}
$$

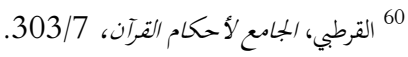


338 | Z. B. GÜNEY مفهوم الأسباط عند الشيخ علي حسن غلوم

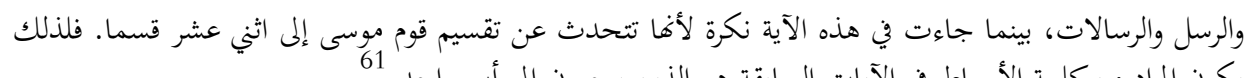

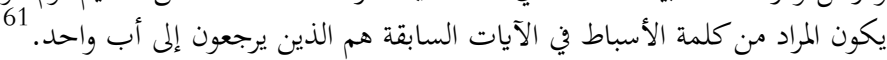

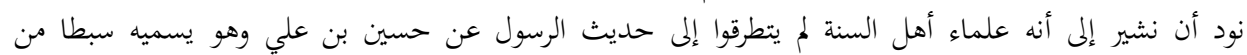

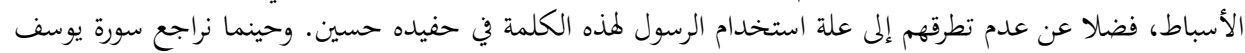

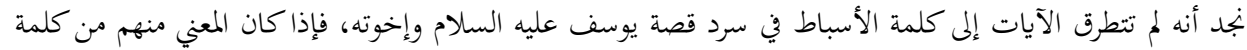

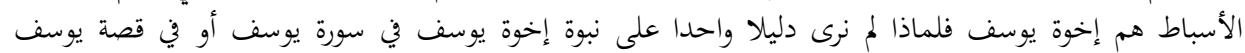

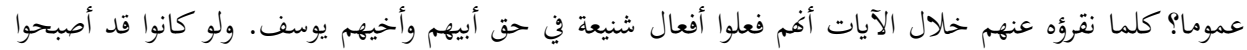

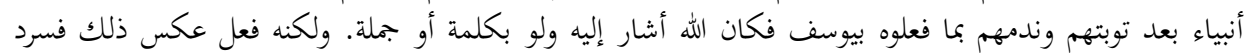

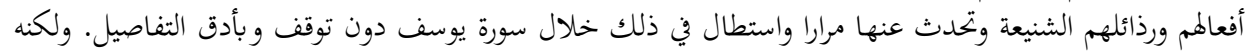

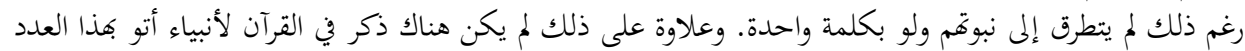

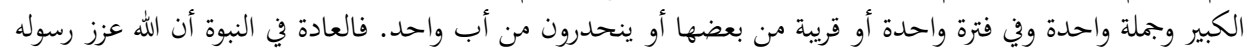

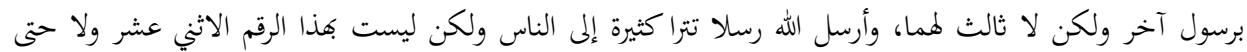

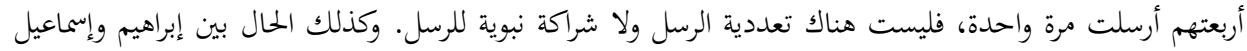

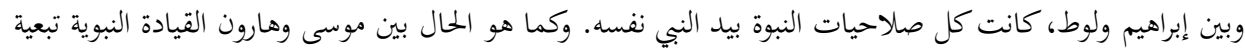

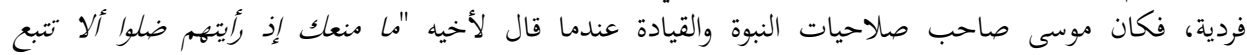

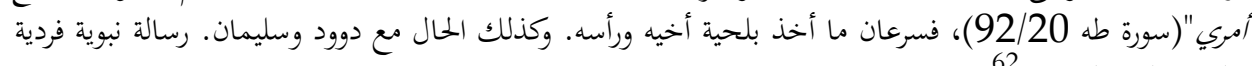

$$
\text { 5. بالإسم المفرد الواضح. }
$$

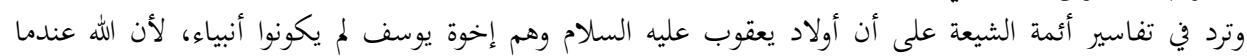

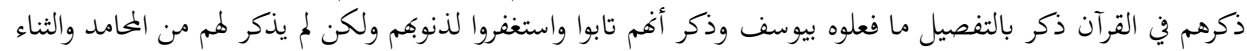

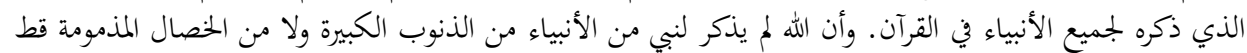

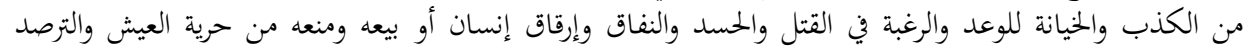

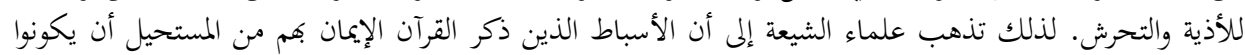

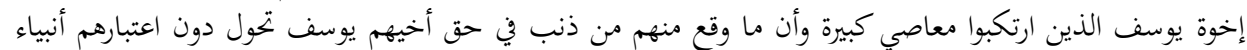

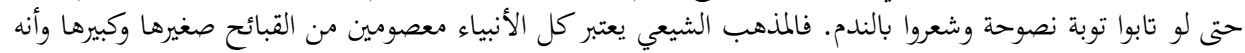

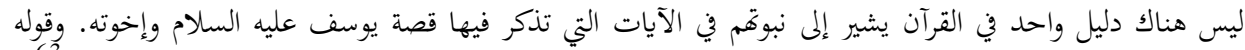

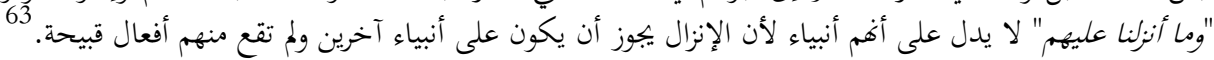

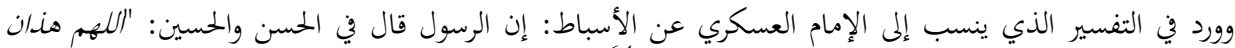

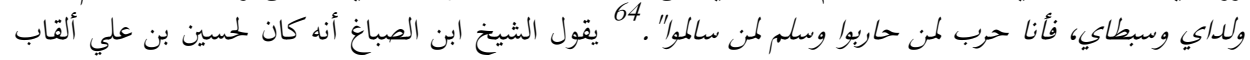

$$
\begin{aligned}
& \text { 61 علي حسن علوم، فك لغز الأسباط، } 27 .
\end{aligned}
$$

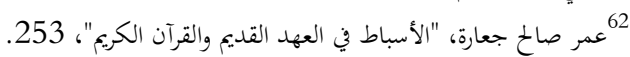

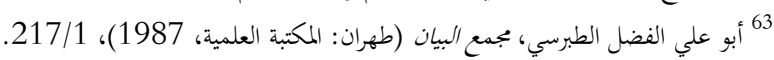

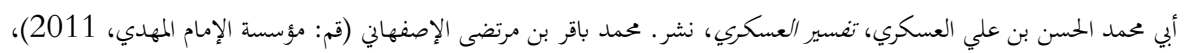


Z. B. GÜNEY / al-Asbât According to Sheikh Ali Hasan Galum I 339

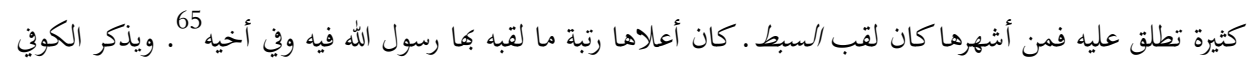

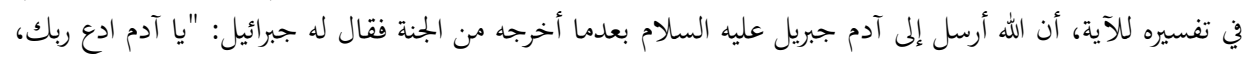

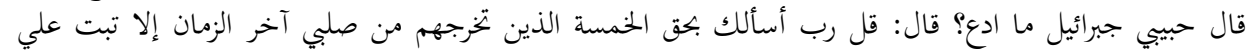

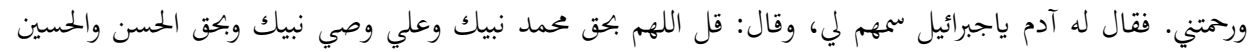

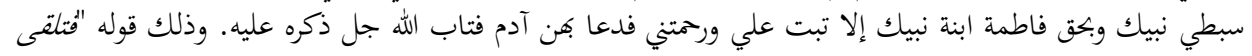

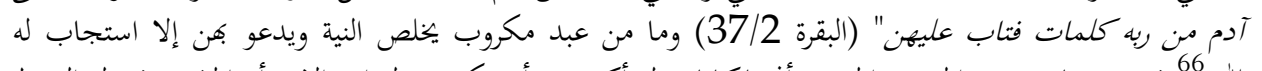

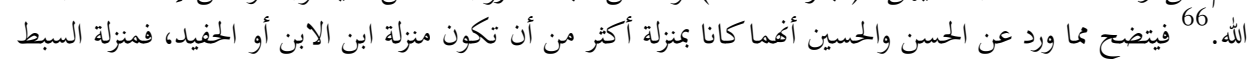

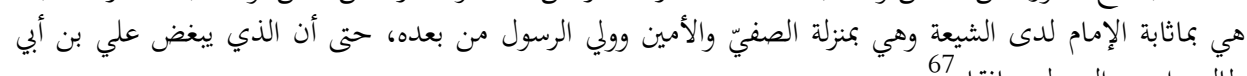
طالب اعتبره الرسول منافقا. وقد ذهب العياشي في تفسيره للآيات التي وردت فيها كلمة الأسباط، ذهب إنب إلى قوله بأفم آل محمد، وأن أولاد إناد

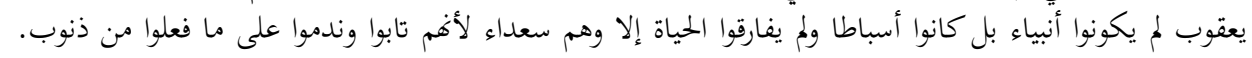

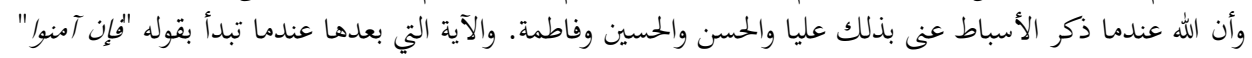

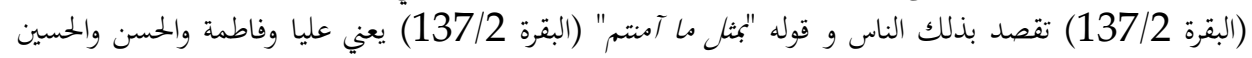

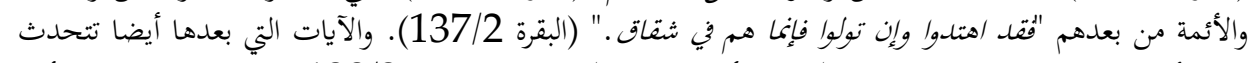

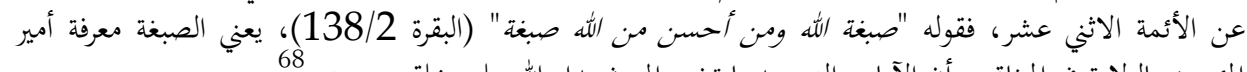

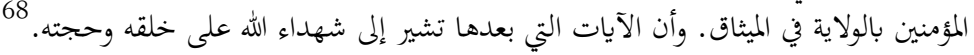

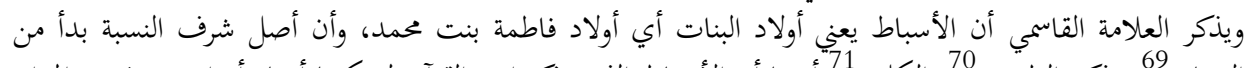

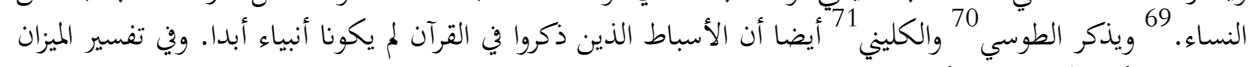

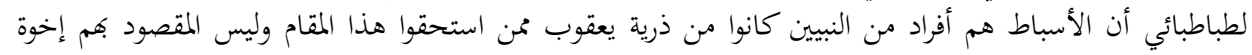

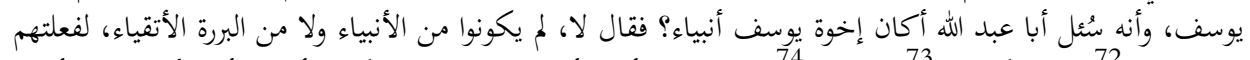

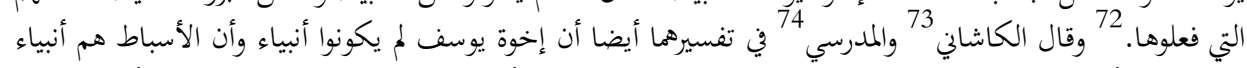

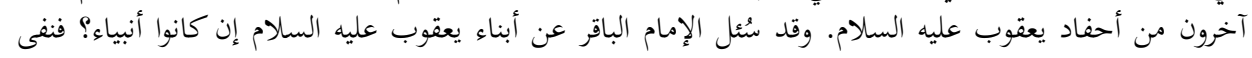

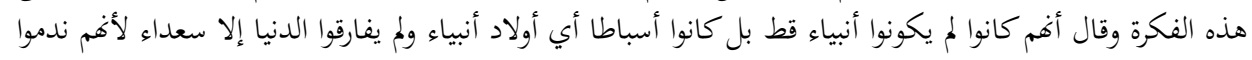

ابن الصباغ علي بن محمد المالكي، الفصول المهمة في معرفة الأئمة، نشر . سامي الغريري (إيران: مؤسسة دار الحديث، 1985)،

.755/2 65

66 فرات بن إبراهيم الكوفي، فرات الكوفي (نجف: الطبعة الحيدرية، 1985)، 195/2، 13/1.

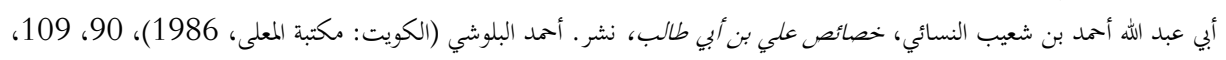

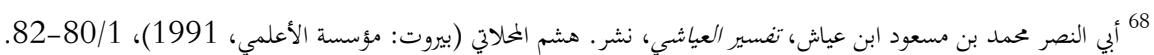

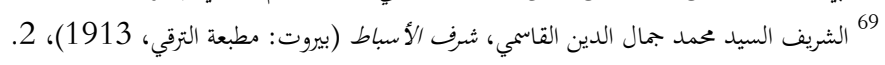

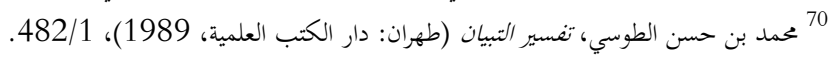

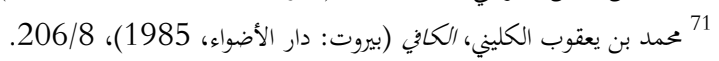

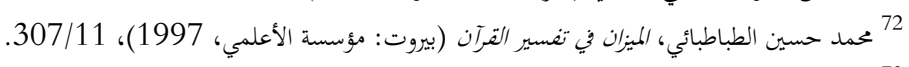

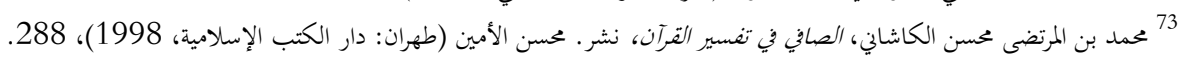

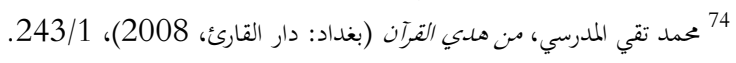




\section{0 | Z. B. GÜNEY / مفهوم الأسباط عند الشيخ علي حسن غلوم}

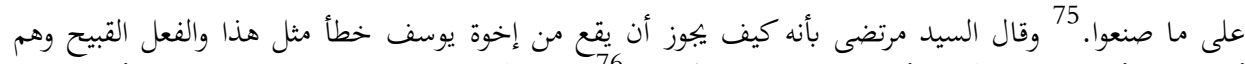
أنبياء؟ من أجل ذلك لم لم يكونوا أنبياء في حال مال من الأحوال.

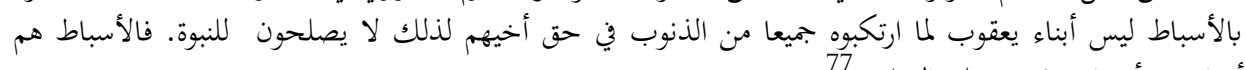
أنبياء من أحفاد يعقوب عليه السلام 78 يتطرق الشيخ الفتوني ${ }^{78}$ والحويزي

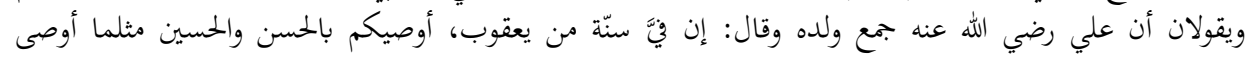

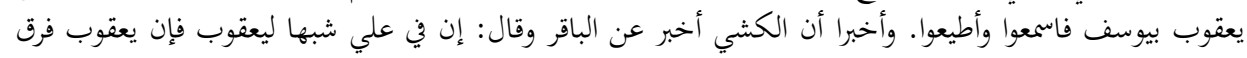

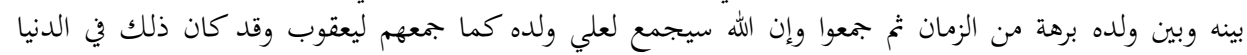

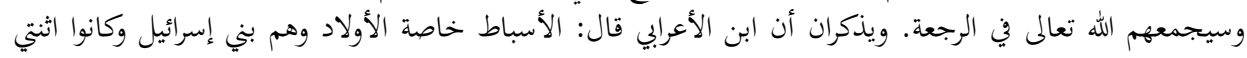

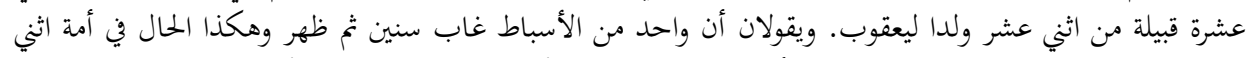

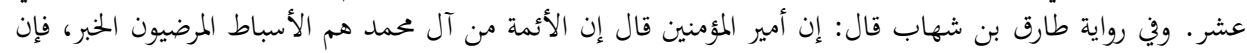

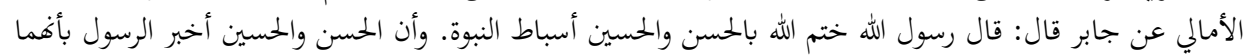

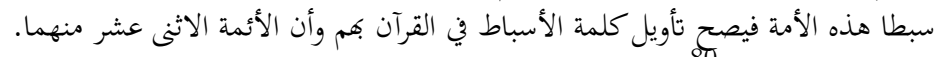

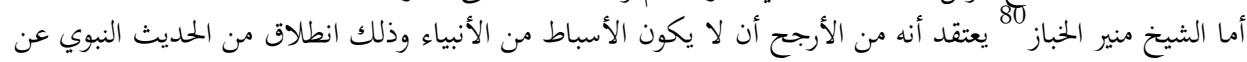

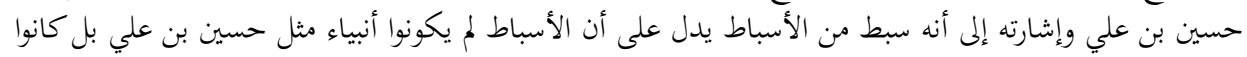

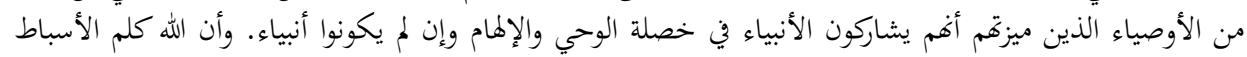

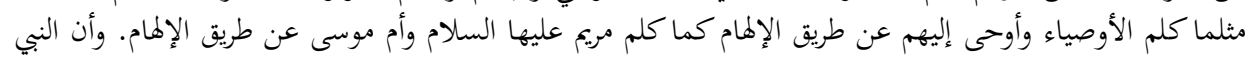

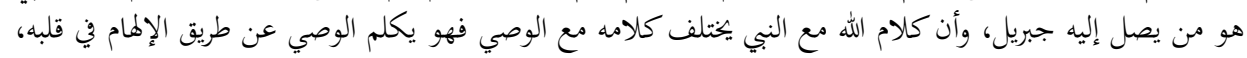

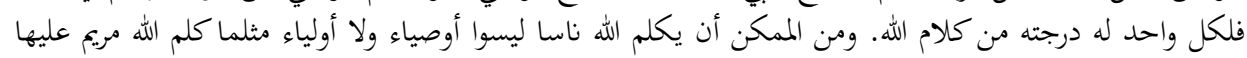

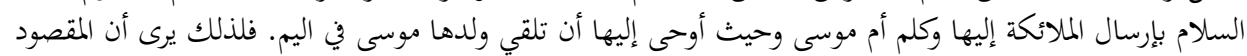

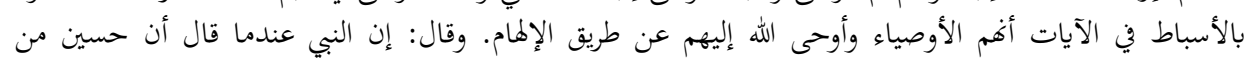

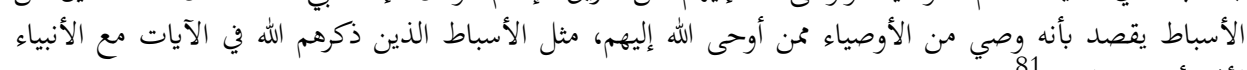
لأفم أوصياء النبوة. 81

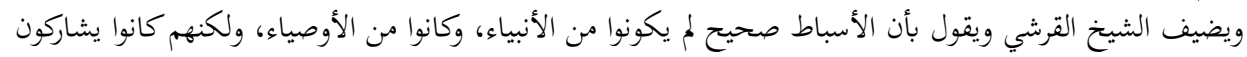

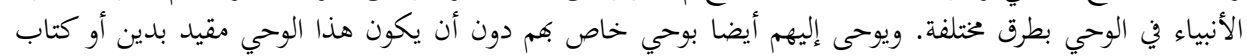

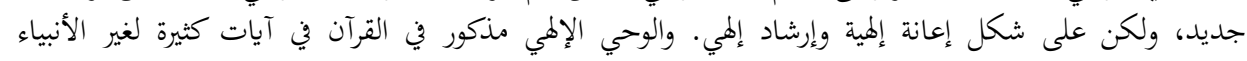

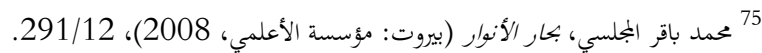

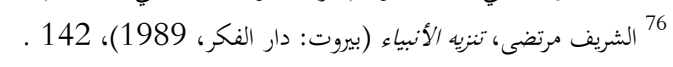

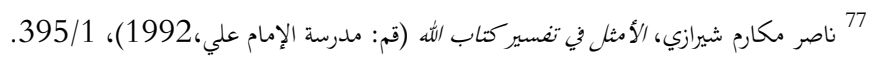

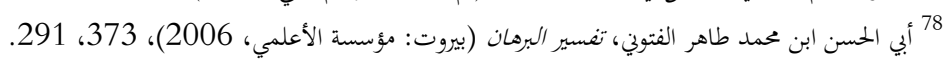

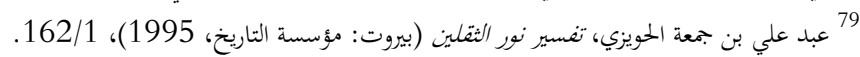
80 80 من علماء الشيعة السعوديين المعاصرين. 
Z. B. GÜNEY / al-Asbât According to Sheikh Ali Hasan Galum | 341 أيضا. 82 فالأسباط لذلك ذكرت في القرآن مع الأنبياء لأغهم أوصياء وخلفاء وورثة الأنبياء والحبل الممدود بين الله وبين الناس. فمسألة الوصي والولي والإمام في المذهب الشيعي أصل ثابت من أصول الإعتقاد؛ فالإمام أعم وأشمل من القائد القائد

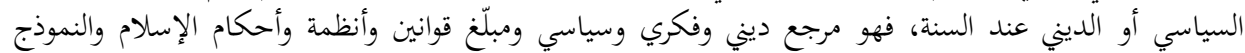

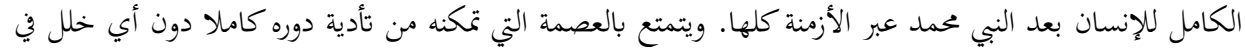

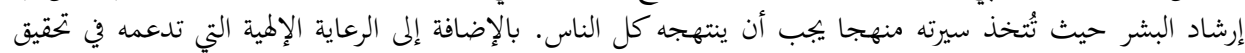

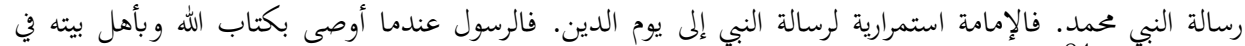

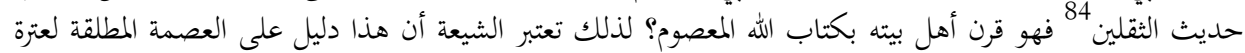

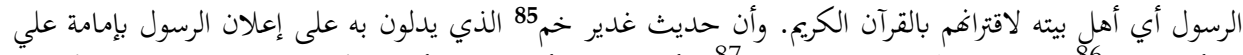

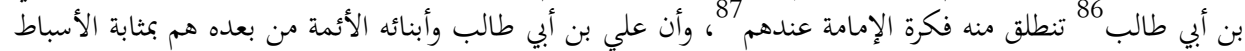

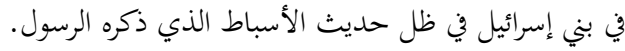

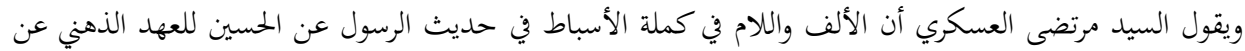

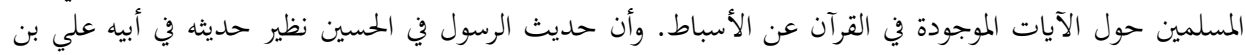

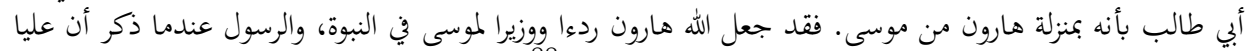

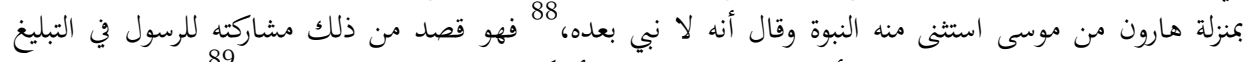

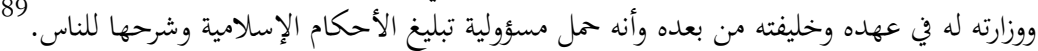

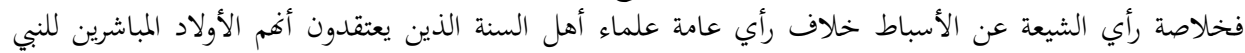

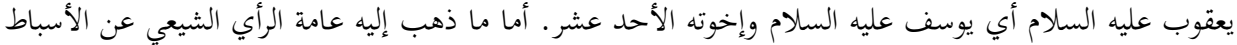

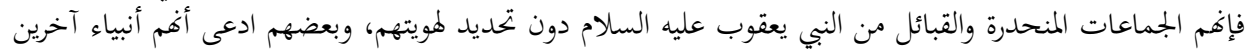

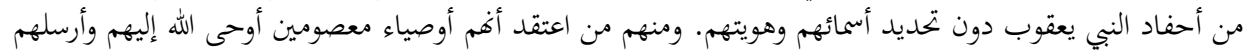

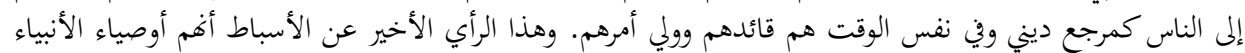

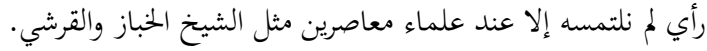

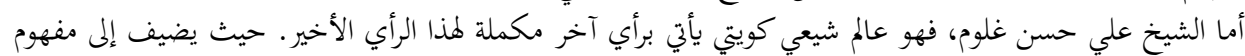

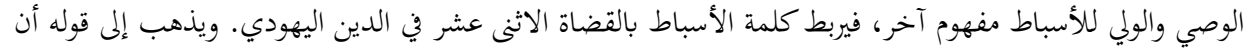

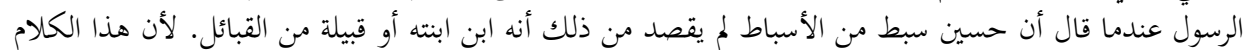

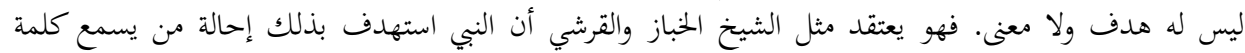

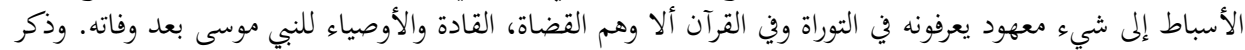

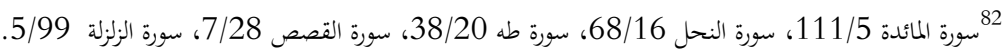

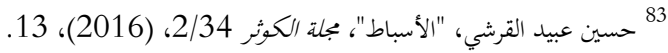

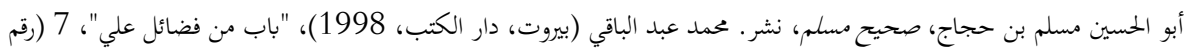

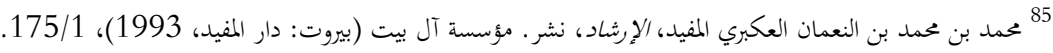

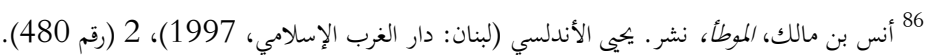

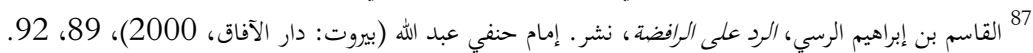

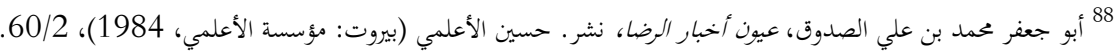

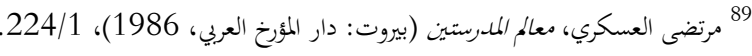


342 | Z. B. GÜNEY / مفهوم الأسباط عند الشيخ علي حسن غلوم

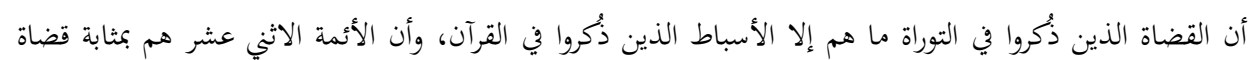

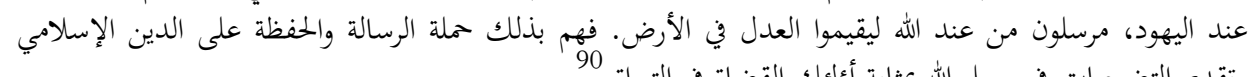

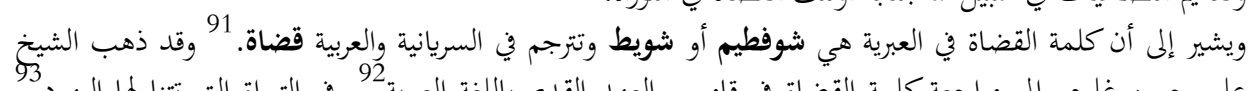

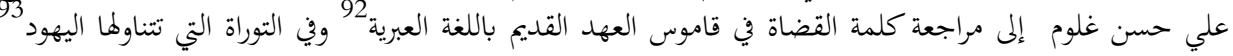

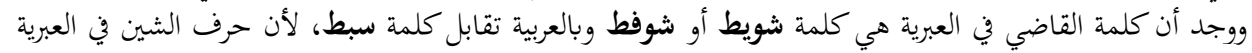

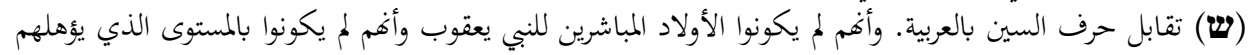

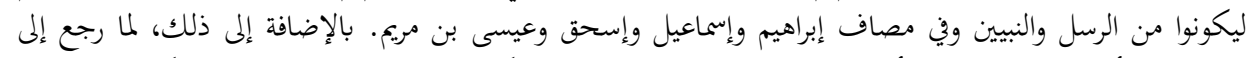

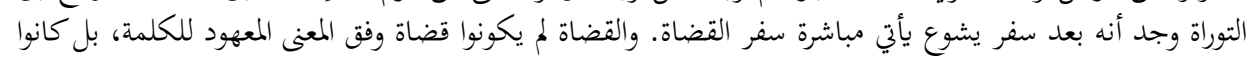

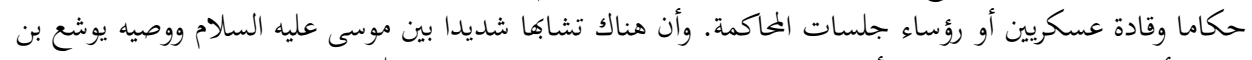

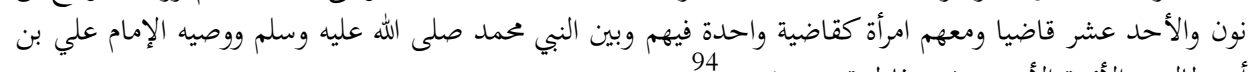

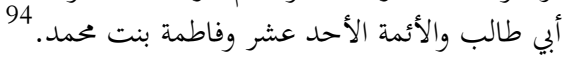

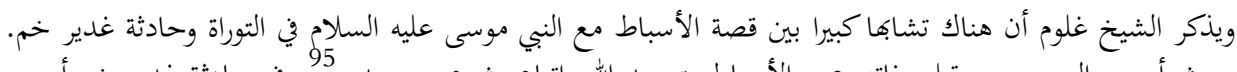

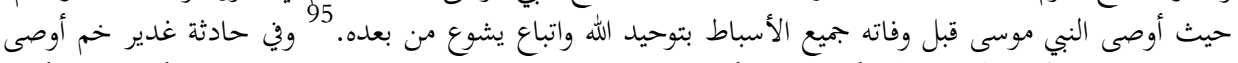

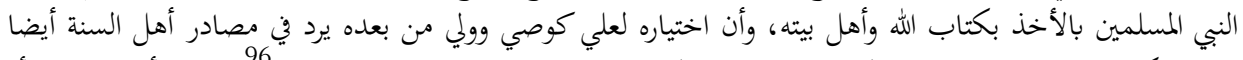

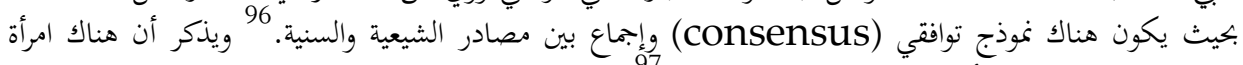

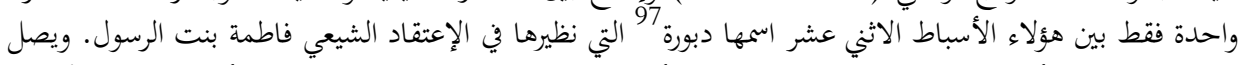

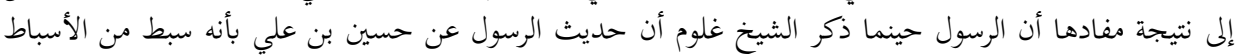

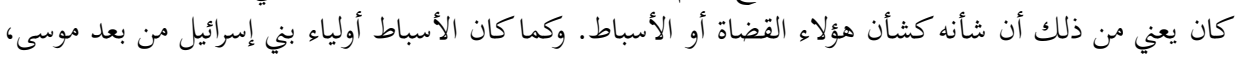

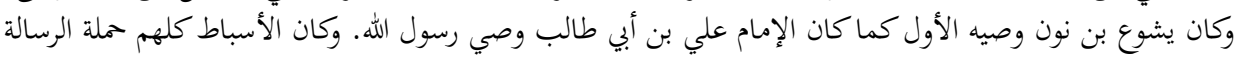

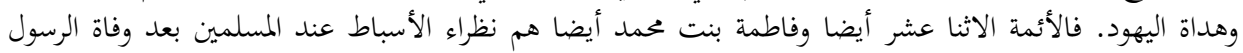

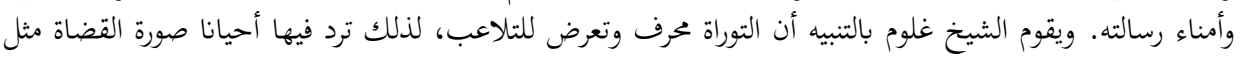

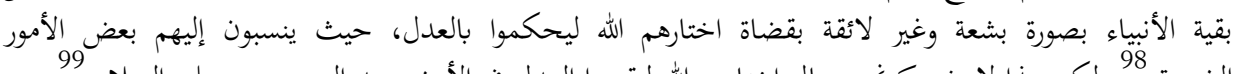

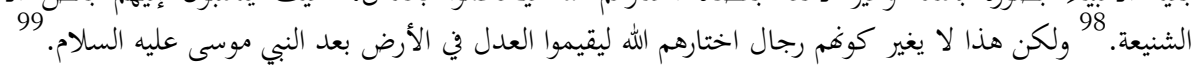

91909 90لي حسن علوم، فك لغز الأسباط، 94. 94.

M. D. Coogan, A Brief Introduction To The Old Testament (London: Oxford Press,

2015), $426 .{ }^{92}$

Chabad, The Torah, "Sefer Shoftim", (Erişim 4 Aralık 2019). ${ }^{93}$

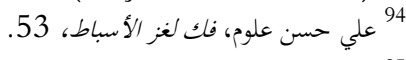

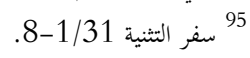

$$
\begin{aligned}
& 96 \text { 9سلم ،"فضائل الصحابة"، } 4 \text { (رقم 2404). } \\
& 97 \text { سفر القضاة } 4 . \\
& 98 \text { سفر القضاة } 15 . \\
& 99 \text { علي حسن علوم، فك لغز الأسباط، 91-93. }
\end{aligned}
$$




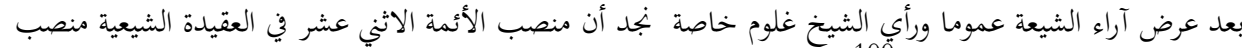

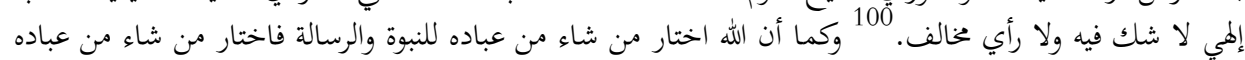

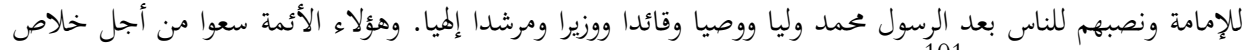

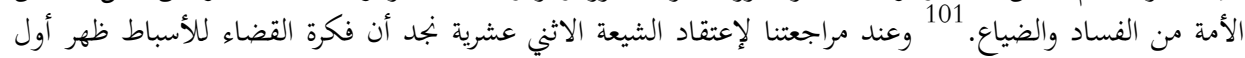

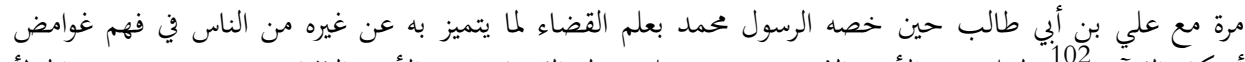

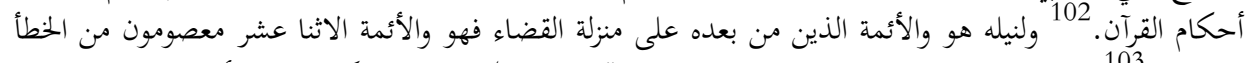

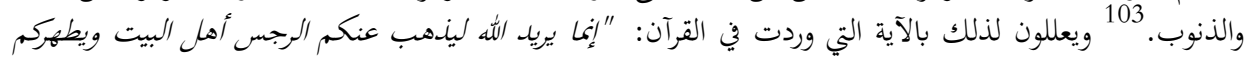

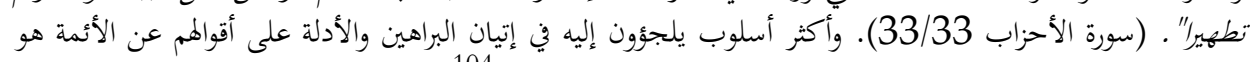

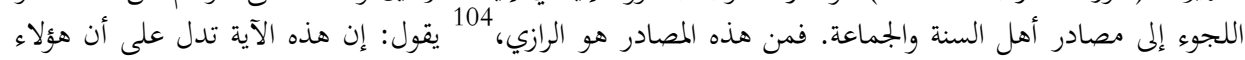

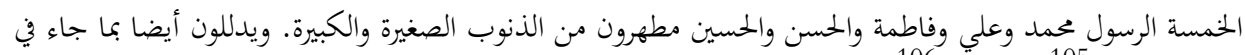

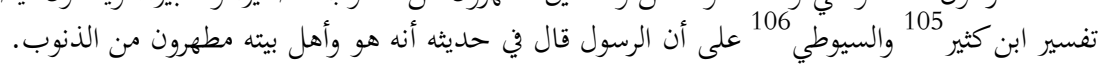

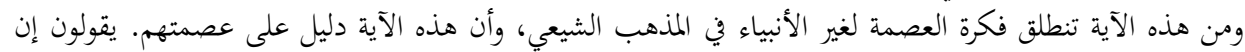

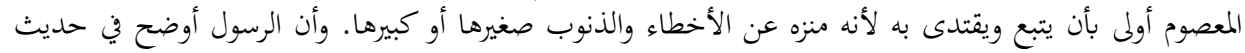

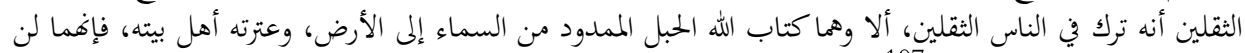
يفترقا حتى يردا على الحوض.

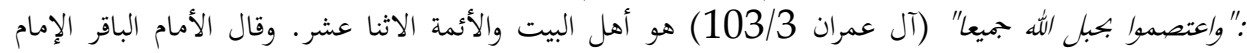

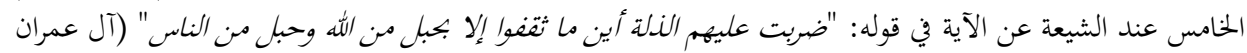

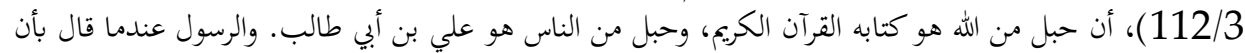

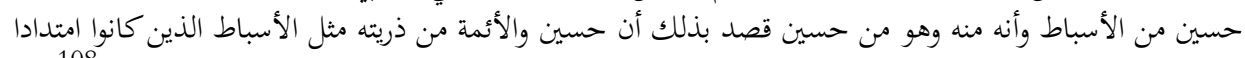

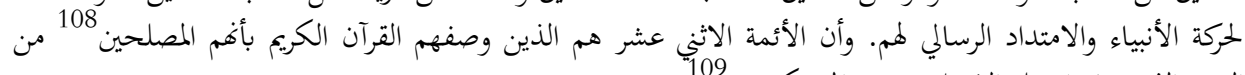
البشر الذين قادوا حملة الإصلاح ضد الإليد المستكبرين.

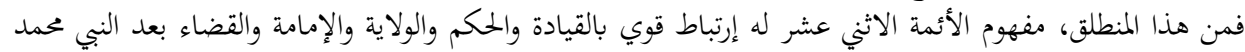

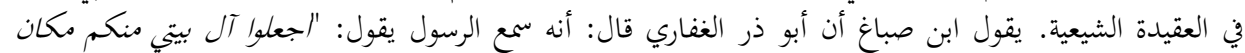

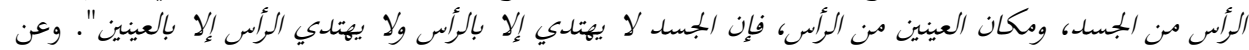

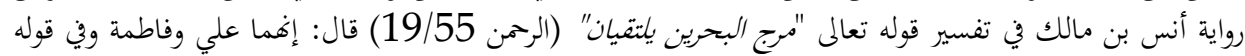

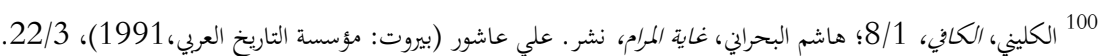

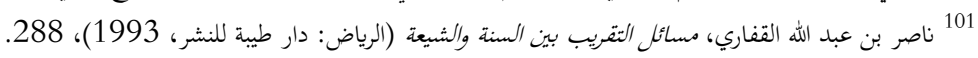

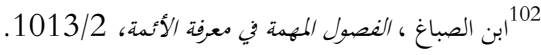
103

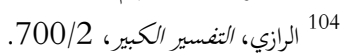

105 ابن كثير، البداية والنهاية (بيروت: مكتبة المعارف، الفير، 1998)، 257/2.

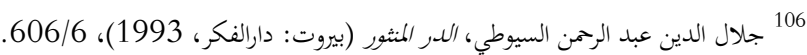
108 107 106

109 محمد باقر موسى جعفر ، الشعائر الحسينية (القراق: العتبة الحسينية، 213 2015)، 24، 27، 36. 
344 | Z. B. GÜNEY مفهوم الأسباط عند الشيخ علي حسن غلوم

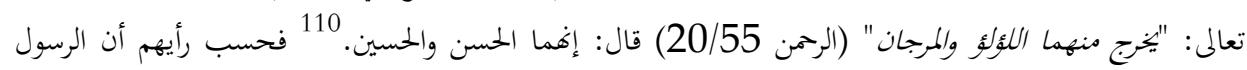

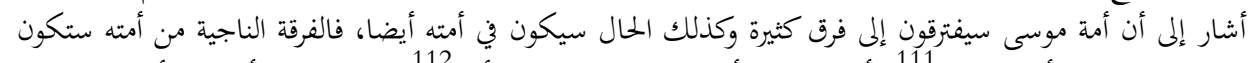

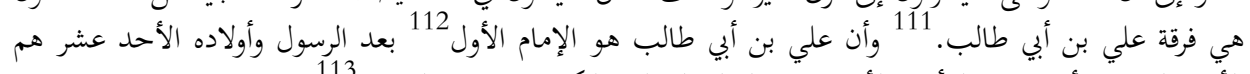

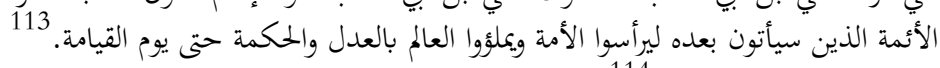

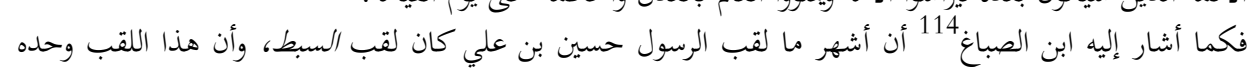

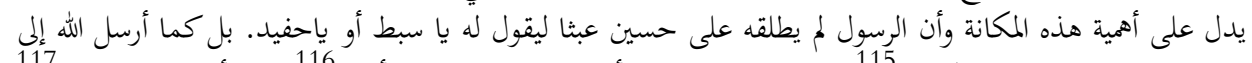

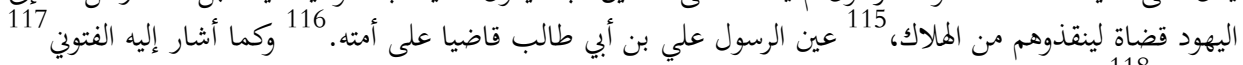

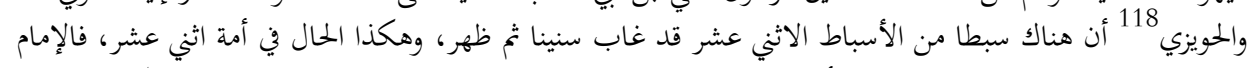

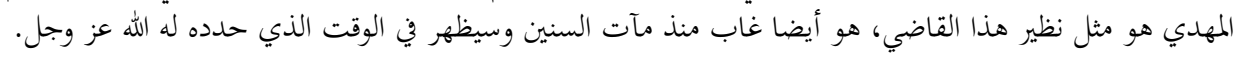

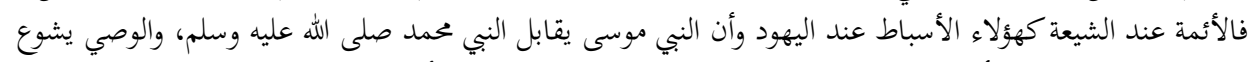

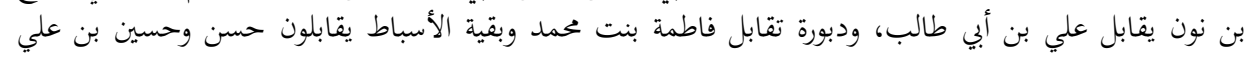

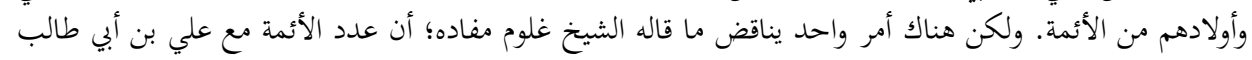

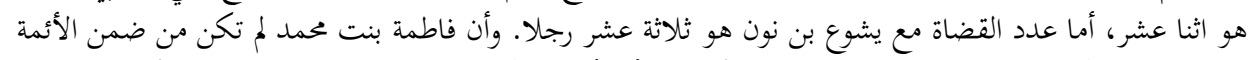

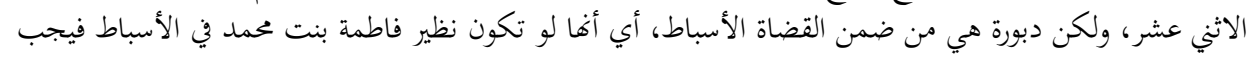

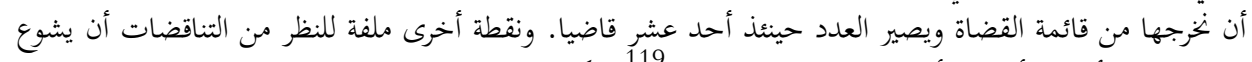

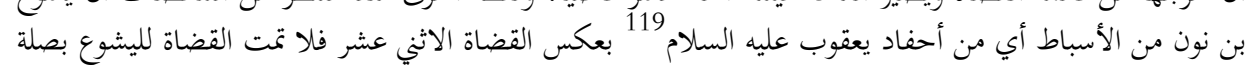

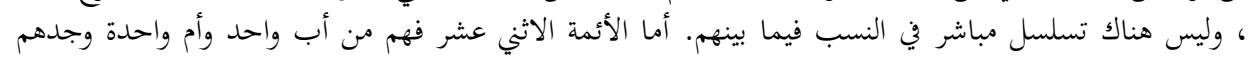

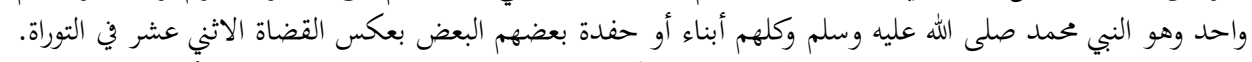

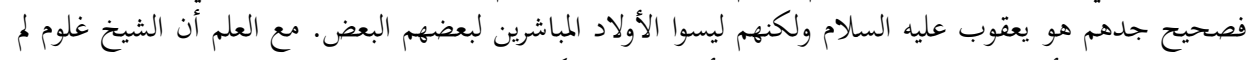

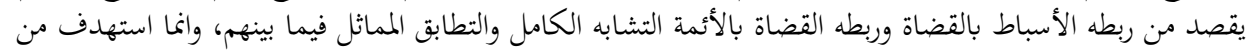

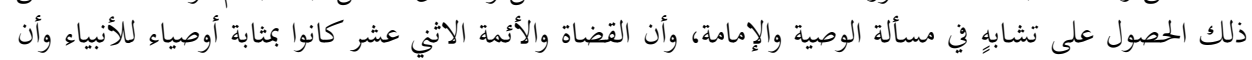

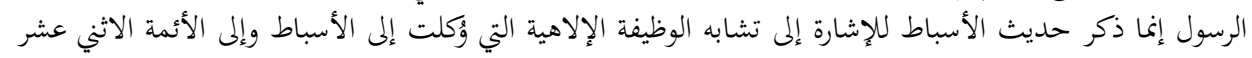
بعد الأنبياء.

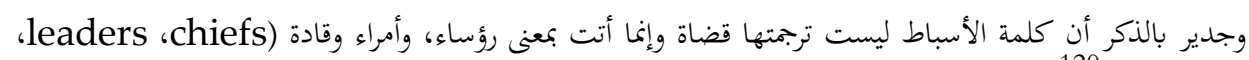

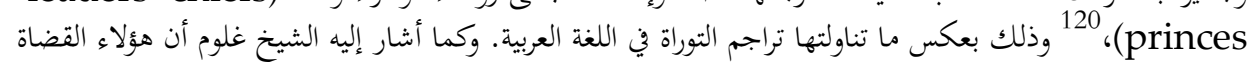

$$
\begin{aligned}
& 110
\end{aligned}
$$

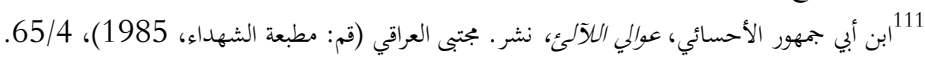

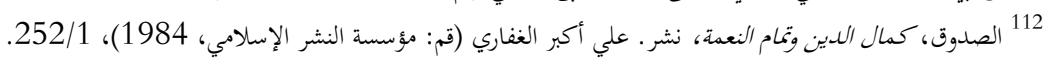

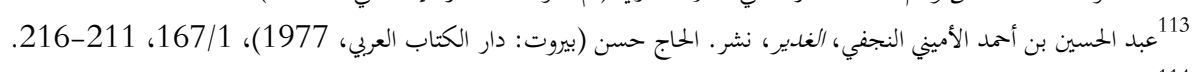

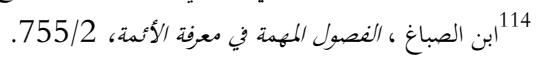

$$
\begin{aligned}
& \text { 115 } 115 \text { سفر القضاة 112/3-16 الصناغ، النصول }
\end{aligned}
$$

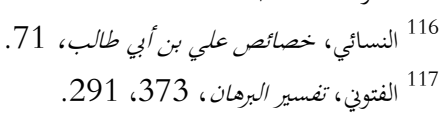

$$
\begin{aligned}
& 118 \text { 118 الحويزي، تفسير نور الثقلين، 162/1 الرهان، } \\
& 119 \text { سفر التكوين 6/48. }
\end{aligned}
$$

Holy Bible, Authorized King James Version (Belgium: Holman Bible Publishers, 1989). ${ }^{120}$ 
Z. B. GÜNEY / al-Asbât According to Sheikh Ali Hasan Galum | 345 حكموا هذه السلالات الأسباط مئات السنين في الفترة التي انقطعت فيها إرسال الرسل والملوك إلى بني إسرائيل. أما

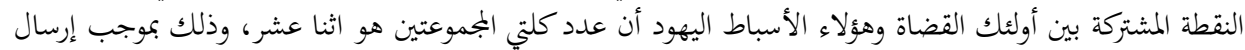
الله إلى كل قبيلة قاض خاص بها ليخلص الشعب من المن ذنوبهم وعبوديتهم للأوثان ويحكم بينهم بالعدل.

في هاية هذا البحث حسُن أن نذكر أهم ما توصلنا إليه من المعلومات. فبعدما راجعنا آراء معظم أعيان العلماء في الثماء

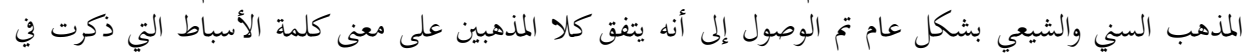

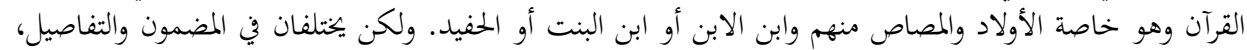

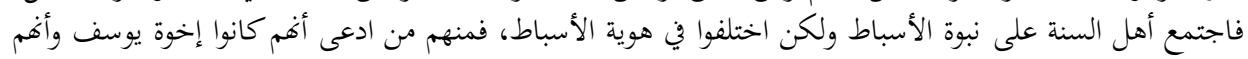

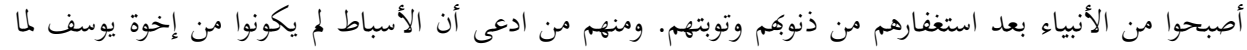

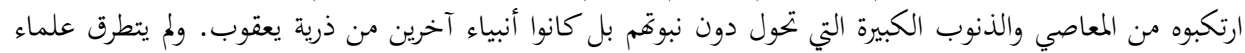

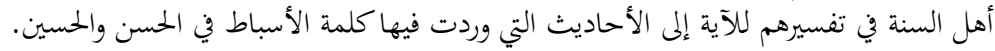

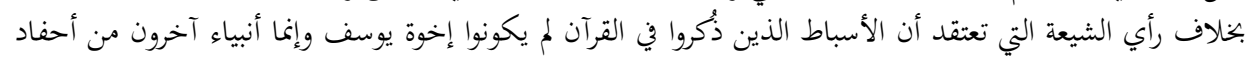

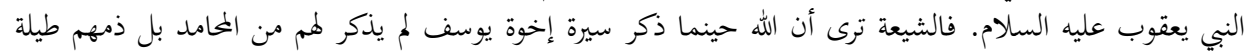

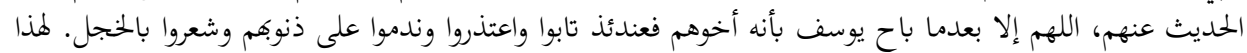

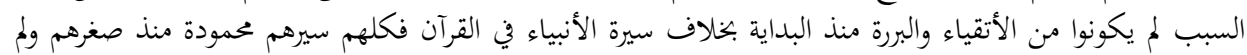

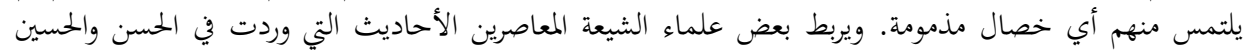

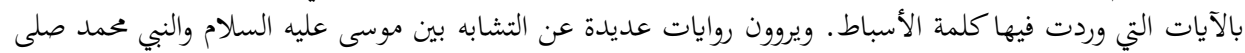

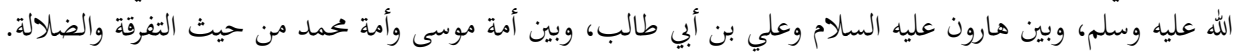

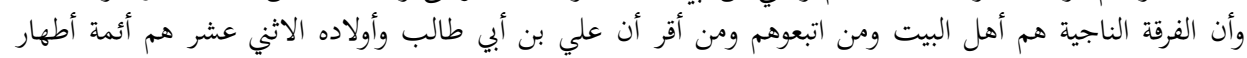
يجب الإقتداء بكم.

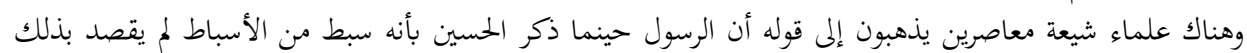

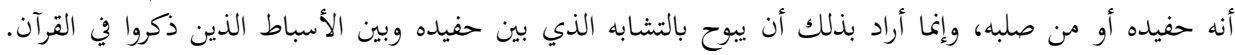

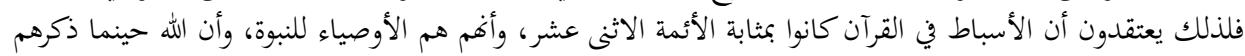

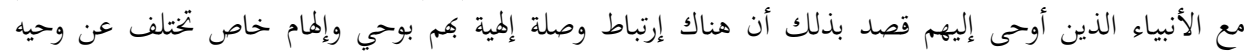

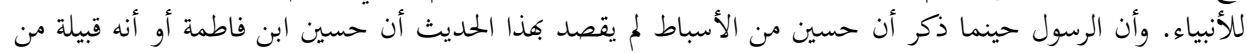

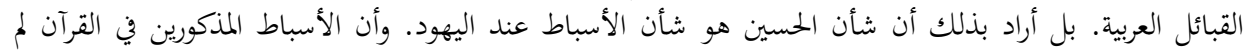

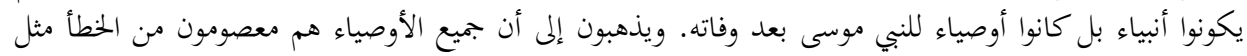

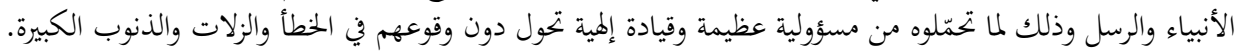

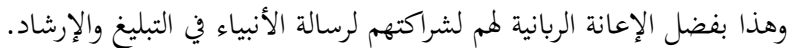

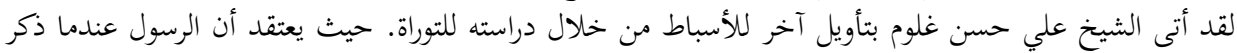

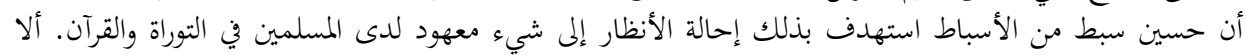

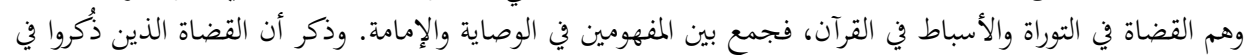

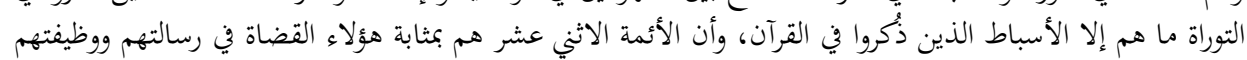

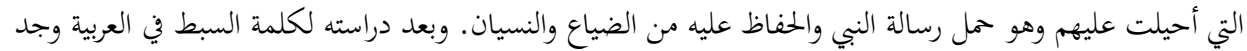

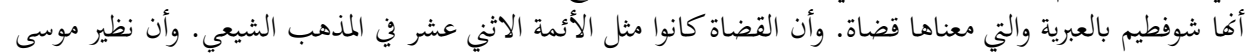

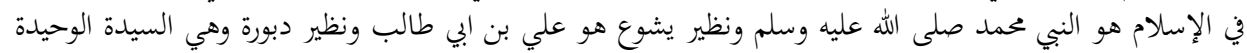

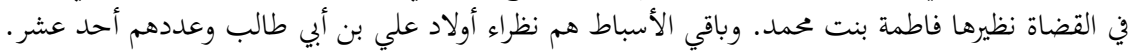


346 | Z. B. GÜNEY / مفهوم الأسباط عند الشيخ علي حسن غلوم

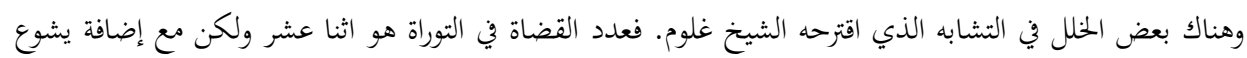

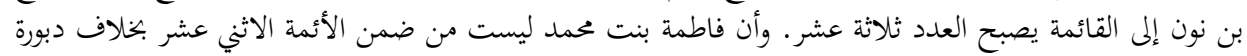

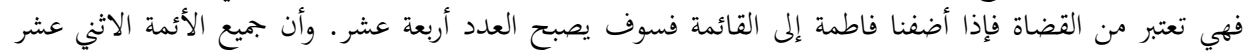

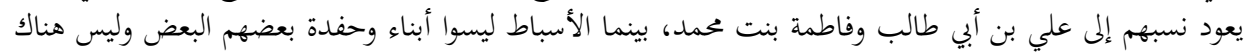

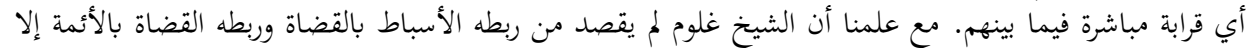

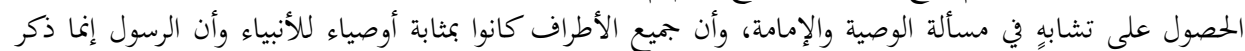

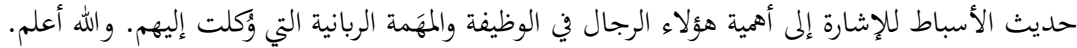

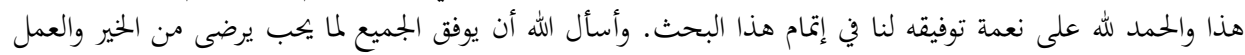

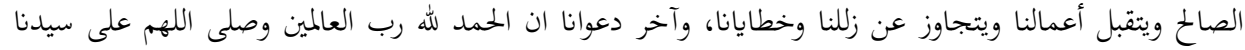
محمد وعلى آله وصحبه أجمعين.

المصادر

ابن الأثير، عز الدين أبي الحسن الجزري. النهاية في غريب الحلديث. نشر. محمود الطناحي. 5 مجلدات. بيروت: المكتبة الإسلامية، 1963.

ابن الصباغ، علي بن محمد المالكي. الفصول المهمة في معرفة الأئمة، نشر. سامي الغريري. مجلدان 2. إيران: مؤسسة

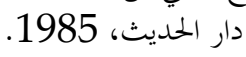

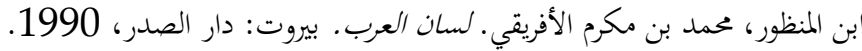

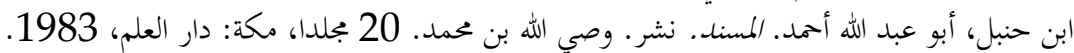

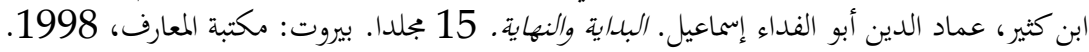

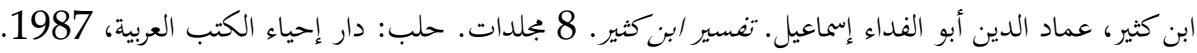

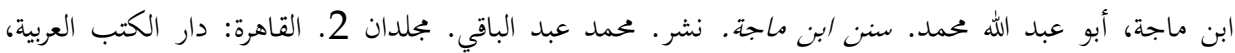

.1930

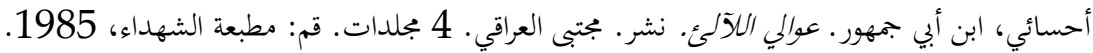

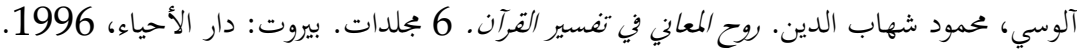

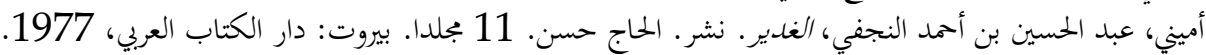

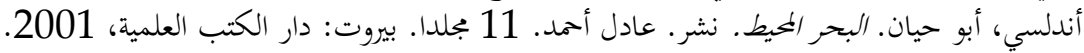

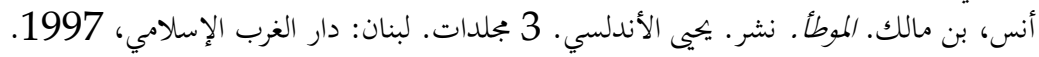

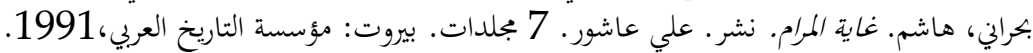

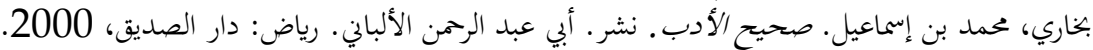

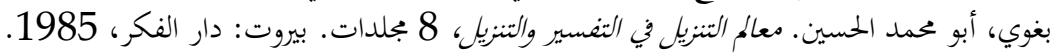

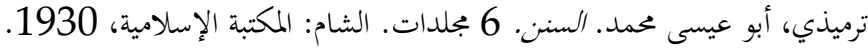

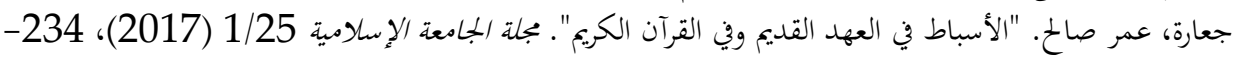

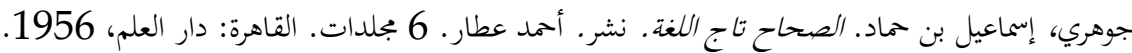

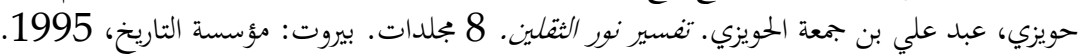

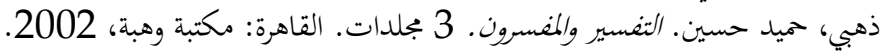

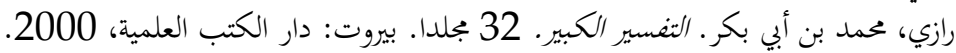

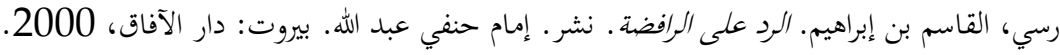


Z. B. GÜNEY / al-Asbât According to Sheikh Ali Hasan Galum | 347

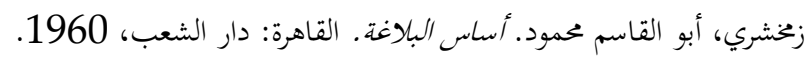

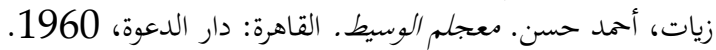

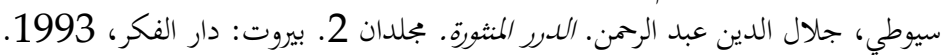

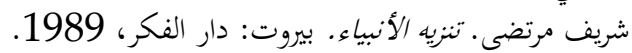

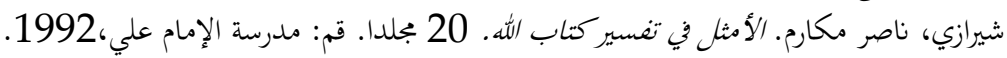

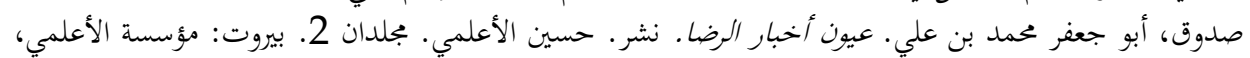
. 1984

صدوق، أبو جعفر محمد بن علي. كمال الدين وتمام النعمة. نشر. علي أكبر الغفاري. بجلدان 2. قم: مؤسسة النشر

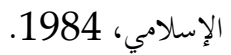

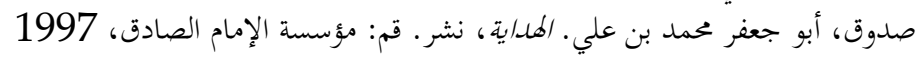

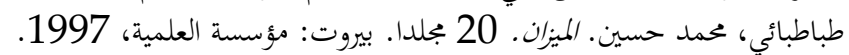

طبرسي، أبو علي الفضل. مجمع البيان. 5 مجلدات. طهران بران: المكتبة العلمية، 1987.

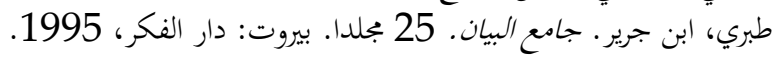

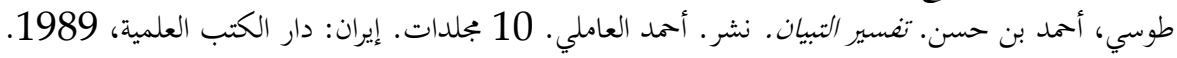

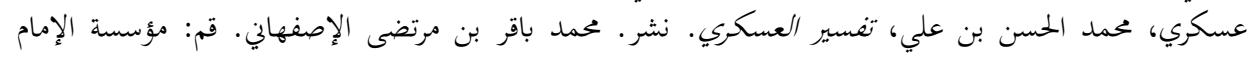

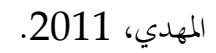

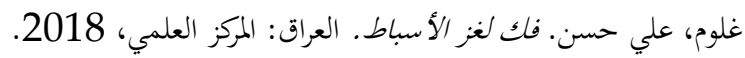

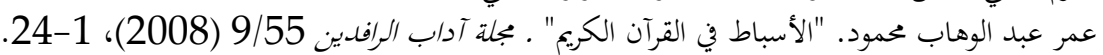

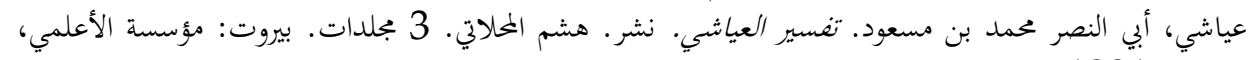
1991

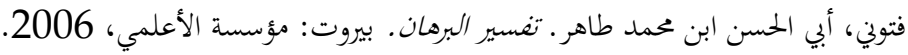

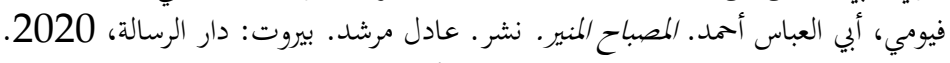

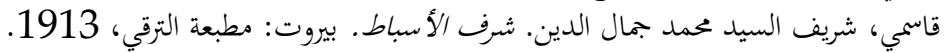

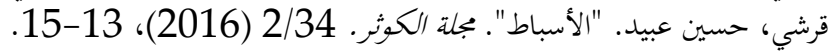

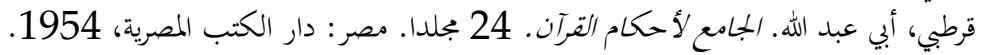

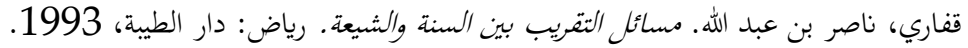

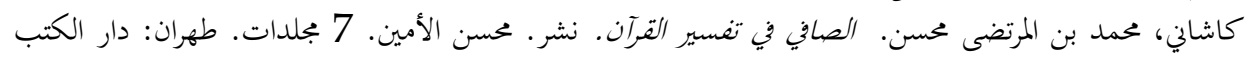

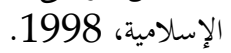

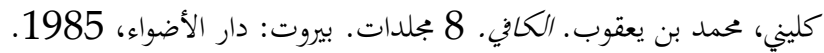
كوفي، فرات بن إبراهيم. فرات الكوفي. 12 مجلدا. نجف: الطبات الطبعة الحيدرية، 1985.

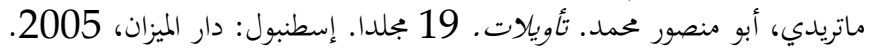

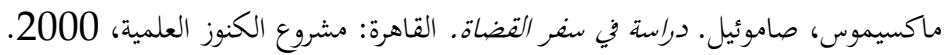

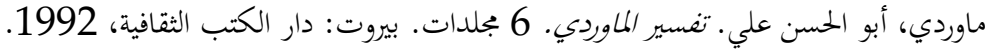

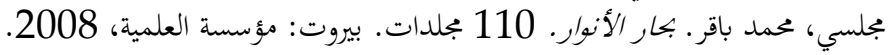

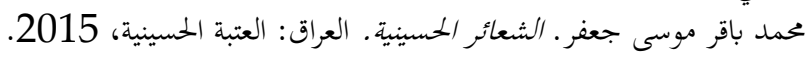

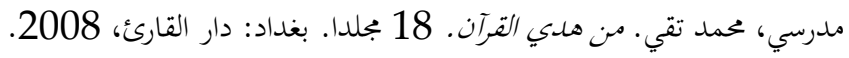




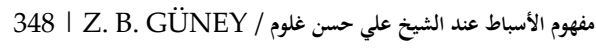

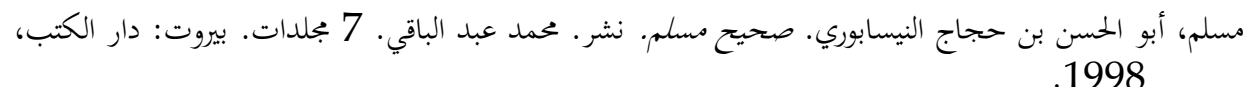

المفيد، محمد بن محمد بن النعمان العكبري. الإشاد. نشر. مؤسسة آل بيت. 11 بجلدا. بيروت: دار المفيد،

1993

نسائي، أبي عبد الله أحمد بن شعيب ـ خصائص علي بن أبي طالب. نشر. أحمد البلوشي. الكويت: مكتبة المعلى،

1986

نيسابوري، محمد بن الحاكم. المستدرك. نشر. مصطفى عبد القادر العطا. 5 مجلدات. بيروت: دار الكتب، 1990.

\section{Kaynakça}

Âlûsî, Mahmud Şihâbe'd-din. Rûhu'l-me ânî fî tefsîri'l-Kur'ân. 6 Cilt. Beyrut: Dâru'l-İhyâ, 1920.

'Askerî, Ebu Muhammed Hasan b. Ali. Tefsîru'l- Askerî. nşr. Muhammed Bakır b.Murtaza el-İsfahanî. Kum: Muessesetu'l-İmâmi'l-Mehdî, 2011.

Ahsâî, İbni Ebî Cumhur. Avâlli'i'l-leâli'. nşr. Muctebâ el-Irâkî. 4 Cilt. Kum: Matbaatu'ş-Şuhedâ, 1985.

'Ayyâşî, Ebi'n-Nasr Muhammed b. Mesud. Tefsîru'l-Ayyâş̂ิ. 3 Cilt. Beyrut: Muessesetu'l-Alemî, 1991.

Begavî, Ebû Muhammed el-Huseyn. Me âlimu't-tenzîl fi't-tefsîr ve't-tenzîl.

8 Cilt. Beyrut: Dâru'l-Fikr, 1985.

Bahrânî, Haşim. Gâyetu'l-merâm. nşr. Ali 'Âşûr. 7 Cilt. Beyrut: Muessesetu't-Târîhi'l-'Arabî, 1991.

Buhârî, Muhammed b. İsmail. Sahîhu'l-edeb. nşr. Ebû Abdurrahman elElbânî. Riyad: Dâru's-Sadîk, 2000.

Ca'âra, Ömer Salih. "el-Esbât fi'l-ahdi'l-kadîm ve Kur'âni'l-Kerîm”. Mecelletu'l-câmi 'atu'l-İslâmiyye 25/1 (2017), 234-256.

Cevherî, İsmail b. Hammâd. es-Sihâh tâcu'l-lugât. nşr. Ahmed 'Attâr. 6 Cilt. Kahire: Dâru'l-İlm, 1956.

Chabad, The Torah. "Sefer Shoftim". Erişim 4 Aralık 2019. https://www.chabad.org/library/article_cdo/aid/1172711/jewish/Se fer-Shoftim.htm.

Coogan, Michael David. A Brief Introduction To The Old Testament. London: Oxford Press, 2005.

Emînî, Abdu'l-Huseyn b. Ahmed en-Necefî. el-Gadîr. nşr. el-Hâcc Hasan. 11 Cilt. Beyrut: Dâru'l-Kutubi'l-'Arabiyye, 1977.

Endelûsî, Ebû Hayyân. el-Bahru'l-muhît. nşr. Adil Ahmed. 11 Cilt. Beyrut: Dâru'l-kutubi'l-ilmiyye, 2001. 
Fettûnî, Ebi'l-Hasan b. Muhammed Tahir. Tefsîru'l-burhân. Beyrut: Muessesetu'l-Alemî, 2006.

Feyyûmî, Ebu'l-Abbas Ahmed. el-Misbâhu'l-munîr. nşr. Adil Murşid. Beyrut: Dâru'r-Risâle, 2020.

Gaffârî, Nâsır b. Abdullah. Mesâilu't-takrîbi beyne's-sunneti ve'ş-şî'a. Riyad: Dâru't-Tîbe, 1993.

Gallûm, Ali Hasan. Fekku lugzu'l-Esbât. Irak: el-Merkezu'l-`i̇lmî, 2018.

Holy Bible. Authorized King James Version. Belgium: Holman Bible Publishers, 1989.

Huveyzî, Abd Ali b. Cuma. Tefsîr-u nûru's-sekaleyn. 8 Cilt. Beyrut: Muessesetu't-Târîh, 1995.

İbni Kesîr, 'İmâde'd-dîn Ebu'l-Fidâ İsmail. el-Bidâye ve'n-nihâye. 15 Cilt. Beyrut: Mektebetu'l-Ma'ârif, 1998.

İbni Kesîr, 'İmâde'd-dîn Ebu'l-Fidâ İsmail. Tefsîru ibni Kesîr. 8 Cilt. Halep: Dâru İhyâe'l-Kutubi'l-`Arabiyye, 1987.

İbni Mâce, Ebû Abdullah Muhammed. Suneni ibni Mâce. nşr. Muhammed Abdulbaki. 2 Cilt. Kahire: Dâru'l-Kutubi'l-Arabiyye, 1930.

İbni Hanbel, Ebû Abdullah Ahmed. el-Mesned. nşr. Vasiyyullah b. Muhammed. 20 Cilt. Mekke: Dâru'l-'ilm, 1983.

İbnu'l-Esîr, İzzeddin Ebi'l-Hasan el-Cuzerî. en-Nihâye fî garîbi'l-hadîs. nşr. Mahmud et-Tannâhî. 5 Cilt. Beyrut: el-Mektebetu'l-İslâmiyye, 1963.

İbnu'l-Manzûr, Muhammed b. Mukrim el-Efrîkî. Lisânu'l- 'Arab. Beyrut: Dârus's-Sadr, 1990.

İbnu's-Sabbâg, Ali b. Muhammed el-Mâlikî. el-Fusûl'ul-muhimme fì ma'rifeti'l-e'imme. nşr. Sami el-Garîrî. 2. Cilt. Beyrut: Muesseset-u Dâri'l-Hadis, 1985.

İmam Mâlik, Ebû Abdillâh Mâlik b. Enes. el-Muvatta'. nşr. Yahya alEndelusî. 3 Cilt. Lübnan: Dâru'l-Garbi'l-İslâmî, 1997.

Kâsımî, Seyyid Muhammed Cemaleddin. Şerefu'l-Esbât. Beyrut: Matbaatu't-Terakkî, 1913.

Kirşî, Huseyn b. 'Ubeyd. "el-Esbât". Mecelletu'l-kevser 34/2 (2016), 13-15.

Kûfî, Furat b. İbrahim. Furât el-Kûfí. 12 Cilt. Necef: et-Tab'atu'lHayderiyye, 1985.

Kuleynî, Muhammed b. Yakub. el-Kâfî. 8 Cilt. Beyrut: Dâru'l-Edvâ, 1985. Kưrtubî, Ebû Abdullah. el-Câmi 'li ahkâmi'l-Kur'ân. 24 Cilt. Misır: Dâru'lKutubi'l-Misriyye, 1954. 
350 | Z. B. GÜNEY / منووم الأسباط عند الشيخ علي حسن غلوم

Maksimus Samuel. Dirâse fî̀ seferi'l-kudât. Kahire: Meşrûi'l-Kunûzi'lİlmiyye, 2000.

Maturidi, Ebu Mansur Muhammed. Tevilât. 19 Cilt. İstanbul: Dâru'1Mizan, 2005.

Mâverdî, Ebu'l-Hasan Ali. Tefsîru'l-Maverdî. 6 Cilt. Beyrut: Dâru'lKutubi's-Sekâfiyye, 1992.

Meclisî, Muhammed Bakır. Bihâru'l-envâr. 110 Cilt. Beyrut: Muessesetu'lİlmiyye, 2008.

Muderrisî, Muhammed Takî. Min huda'l-Kurân. 18 Cilt. Bağdad: Dâru'lKârî, 2008.

Mufîd, Muhammed b. Muhammed b. en-Numân. el-İrşâd. nşr. Muesseset-u Âl-i Beyt. Beyrut: Dâru'l-Mufîd, 1993.

Muhammed Bakır Musa Cafer. eş-Şe 'âiru'l-huseyniyye. Irak: el-'Atabetu'lHuseyniyye, 2015.

Muslim, Ebu'l-Huseyn b. Haccac en-Nîsâbûrî. Sahîh Muslim. nşr. Muhammed Abdulbaki. 7 Cilt. Beyrut: Dâru'l-Kutub, 1998.

Nîsâbûrî, Muhammed b. el-Hâkim. el-Mustedrek. nşr. Mustafa Abdulkadir el-'Atâ. 5 Cilt. Beyrut: Dâru'l-Kutub, 1. Basım, 1990.

Nisâî, Ebî Abdullah Ahmed b. Şuayb. Hasâis-u Ali b. Eb̂̂ Tâlib. nşr. Ahmed el-Bellûşî. Kuveyt: Mektebetu'l-Ma'lâ, 1986.

Ömer Abdulvahhab Mahmud. "el-Esbât fi'l-Kurâni'l-Kerîm". Mecelletu adâbi'r-râfidîn 55/9 (2008), 1-24.

Rassî, Kasım b. İbrahim. er-Radd-u 'ala'r-râfida. nşr. İmam Hanefi Abdullah. Beyrut: Dâru'l-Afâk, 2000.

Râzî, Muhammed b. Ebî Bekir. et-Tefsîru'l-kebîr. 32 Cilt. Beyrut: Dâru'lkutubi'l-ilmiyye, 2000.

Sadûk, Ebu Cafer Muhammed b. Ali. Kemâlu'd-dîn ve temâmu'n-nime. nşr. Ali Ekber el-Gaffârî. 2 Cilt. Kum: Muessesetu'n-Neşri'l-İslâmî, 1984.

Sadûk, Ebu Cafer Muhammed b. Ali. 'Uyûn-u ahbâr-i Rıdâ. nşr. Huseyn el-Alemî. Beyrut: Muessesetu'l-Alemî, 1984.

Suyûtî, Celâleddin Abdurrahman. ed-Dureru'l-mensûra. 2 Cilt. Beyrut: Dâru'l-Fikr, 1993.

Şerif Murtazâ. Tenzîhu'l-enbiyâ. Beyrut: Dâru'l-fikr, 1989.

Şîrâzî, Nasır Mekârim. el-Emsel fì tefsir-i kitâbi'l-lâh. 20 Cilt. Kum: Medresetu'l-İmâm Ali, 1992.

Tabatabâî, Muhammed Huseyn. el-Mîzân. 20 Cilt. Beyrut: Muessesetu'lİlmiyye, 1997. 
Taberî, İbnu Cerîr. Câmi 'u'l-beyân. 25 Cilt. Beyrut: Dâru'l-Fikr, 1995.

Tabersî, Ebû Ali el-Fadl. Mecme 'ul-beyân. 5 Cilt. Tahran: el-Mektebetu'lİlmiyye, 1987.

Tirmîzî, Ebû İsâ Muhammed. es-Sunen. 6 Cilt. Şam: el-Mektebetu'lİslâmiyye, 1930.

Tûsî, Ahmed b. Hasan. Tefsîru't-tibyân. nşr. Ahmed el-`Âmilî. 10 Cilt. İran: Dâru'l-kutubi'l-ilmiyye, 1989.

Zehebî, Hamid Huseyn. et-Tefsîr ve'l-mufessirûn. 3 Cilt. Kahire: Mektebetu Vehbe, 1986.

Zemahşerî, Ebu'l-Kâsım Mahmud. el-Keşşâf. nşr. Halil Şeyhạa. Beyrut: Dâru'l-Meârif, 2002.

Zemahşserî, Ebu'l-Kâsım Mahmud. Esâsu'l-belâgat. Kahire: Dâru'ş-Şa'ab, 1960.

Zeyyât, Ahmed Hasan. Mu 'cemu'l-vasît. Kahire: Dâru'd-Da 've, 1960.

Zimmerli, Walther. The law and the prophets. USA: Wipf - Stock Publishers, 2010. 